\title{
Structural control on gold mineralization in the Satulinmäki and Riukka prospects, Häme Schist Belt, southern Finland
}

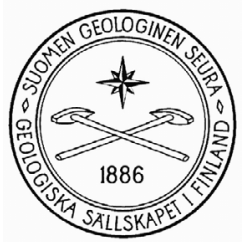

\author{
Kerstin SaAlmanN \\ Geological Survey of Finland, P.O. Box 96, FI-02151 Espoo, Finland
}

\begin{abstract}
The Satulinmäki and Riukka prospects located in the Häme Schist Belt in southern Finland are dominated by mafic and intermediate to felsic metavolcanic rocks of the Forssa Group formed in a continental arc setting. This magmatic belt formed some 1890 - I880 Ma ago and has been deformed during the Svecofennian orogeny. The dominant penetrative foliation is represented by $S_{n+1}$, which is axial planar to $\mathrm{cm}$ - to $\mathrm{dm}$-scale iscolinal $\mathrm{F}_{\mathrm{n}+1}$ folds and thus parallel to the layering $S_{n}$. Associated ductile shearing might reflect early thrusting. $D_{n+2}$ post-dating peak metamorphism is characterized by small-scale to regional-scale refolding of $\mathrm{F}_{n+1}$ folds around $\sim \mathrm{SW}-\mathrm{NE}$ fold axes. This phase is transitional to development of SW-NE to WSW-ENE and NW-SE striking shear zones and faults formed due to dextral transpression during $D_{n+3}$ at retrograde conditions crossing the brittle-ductile transition. Many mineralized quartz veins have formed during this event. Later faults and quartz veins and reactivation of pre-existing structures during $D_{n+4}$ indicate rotation of the stress field to $\sim N E$ SW oriented compression. A clear $\sim$ SW-NE trend of sulphide mineralization and elevated gold contents and the spatial association to $D_{n+3}$ quartz veins, shear zones and faults suggest a strong structural control, typical of orogenic gold deposits, and that mineralization took place during $D_{n+3}$. The controlling structures, (i) WSW-ENE to SW-NE shear zones and faults and (ii) NW-SE oriented fault, are second and third order structures to major regional-scale shear zones. The fault zones and their intersection points impart a directional permeability so that the mineralising fluids were channelled along dilatant zones. Approximately (W)NW-(E)SE trending faults being (re)activated as extensional faults or dilatant shear planes during $D_{n+3}$ transpression with WNW-ESE to NW-SE oriented compression direction could have acted as conduits for fluids during upward flow from deeper crustal level. Future studies in this area are necessary to test if other prospects show similar timing and structural control, and future exploration for finding new targets should consider sites of (W)SW-(E)NE and NW-SE-striking second and third-order structures branching from major shear and fault zones.
\end{abstract}

Key words: gold ores, metavolcanic rocks, mineralization, quartz veins, structural controls, deformation, shear zones, faults, Proterozoic, Satulinmäki, Riukka, Finland

e-mail: kerstin.saalmann@gtk.fi 


\section{Introduction}

Many studies of gold deposits in Finland have been carried out since the 1980s focussing on their potential and genetic type. Most gold deposits in the Svecofennian domain of Finland are orogenic, some represent metamorphosed epithermal deposits (Eilu et al., 2003). Orogenic gold deposits (Groves et al., 1998 ) occur in variably metamorphosed rocks. They are structurally controlled and spatially associated with shear zones and hydrothermal veins formed in response to the regional stress field. Faults and shear zones are potential pathways of fluids (e.g. Sibson $\&$ Scott, 1998) and thus, knowledge of the structural architecture of a mineralized area, the distribution and orientation of faults and shear zones, their formation and possible reactivation during the structural evolution and the tectonic conditions is a key to under- standing the formation, origin and location of mineral deposits as well as for exploration and findings of new targets.

The study area is located in the Häme Schist belt in southern Finland between the towns of Forssa in the north and Somero in the south (Fig. 1). The occurrence of gold was recognized by detection of mineralized quartz veins (Riukka) or gold-rich erratic boulders (Satulinmäki) prompting to geological mapping and drilling. The gold is commonly spatially associated with quartz veins in polydeformed and metamorphosed rocks indicating a classification of the deposits as orogenic. Hence, the relationship of mineralization to quartz vein formation and tectonic structures, and consequently the formation of these structures during the tectono-metamorphic evolution of this area are crucial in order to build a model of the gold occurrences. This paper focuses on the structur-

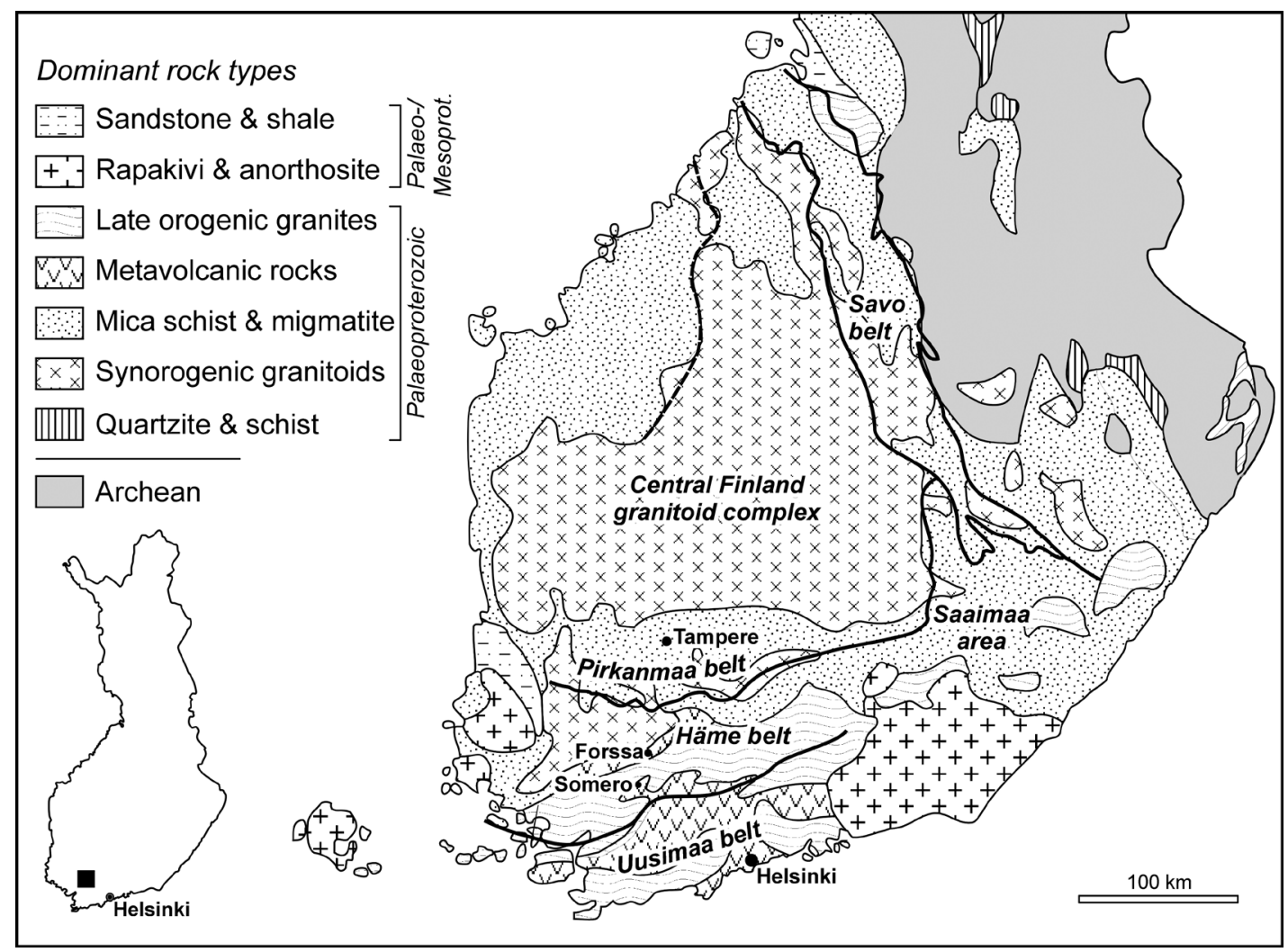

Fig. I. Simplified geological map of southern Finland. The study area is located in the Häme belt between Forssa and Somero. 
al aspects of the prospects; future work has to include geochemical investigations as well as dating of mineralization.

\section{Geological setting}

The Fennoscandian Shield in Finland comprises Archean cratons in the north and east, which are bordered by the Palaeoproterozoic Svecofennian domain in the west and south. Svecofennian rocks have ages mainly between $1.93 \mathrm{Ga}$ and $1.8 \mathrm{Ga}$; however, isotopic data point to the existence of older, $2.1-2.0 \mathrm{Ga}$ source rocks (Lahtinen \& Huhma, 1997; Rämö et al., 2001). The Svecofennian orogenic cycle was a period of considerable crustal growth between $2.1 \mathrm{Ga}$ and $1.8 \mathrm{Ga}$ (e.g. Huhma et al., 1991; Lahtinen \& Huhma, 1997; Rämö et al., 2001; Lahtinen et al., 2005).

On the basis of lithological content and their geographical distribution the Svecofennian domain can be subdivided into several geological areas, complexes and belts (Vaasjoki et al., 2005). However, these units do not necessarily correlate with tectono-stratigraphic blocks and terranes, and bordering faults and shear zones do not necessarily correspond to major boundaries or sutures between tectonic blocks.

The approximately WSW-ENE-trending Häme belt is located in the southern part of the Svecofennian domain. It is bordered by the Pirkanmaa belt to the north and the Uusima belt to the south (Fig. 1). Volcanic rocks are the dominant lithologies within the Häme belt ranging from basalt to rhyolite with andesitic rocks being the most common types (Hakkarainen, 1994; Kähkönen, 2005). Metasedimentary rocks are intercalated with the metavolcanic rocks. In addition, syntectonic plutonic rocks of gabbroic, dioritic, granodioritic and tonalitic composition intruded into the succession (Fig. 2). The rocks were metamorphosed at amphibolite conditions with the metamorphic grade increasing to the south leading to local migmatisation and partial melting. Late-tectonic K-granites and pegmatitic veins are the youngest magmatic rocks.

Hakkarainen (1994) subdivides the volcanic rocks into the lower Forssa Group and the Häme Group.
Metasedimentary rocks between the groups are not subdivided. The basement of the Forssa Group is not known (Hakkarainen, 1994), though Lahtinen (1996) suggests that it could consist of greywackes. The Forssa Group comprises metavolcanic and metamorphosed pyroclastic rocks. Andesitic rocks are most abundant, but felsic rocks are widespread, too. Locally, andesitic pillow lavas are preserved. Metapelitic rocks, which are derived mainly from volcanic debris (Lahtinen, 1996), are intercalated with the metavolcanic and -pyroclastic rocks. Geochemically, the calc-alkaline metavolcanic rocks show a subduction zone component and arc-affinity (Hakkarainen, 1994; Lahtinen, 1996) and thus, the Forssa Group represents a volcanic arc setting. The Häme Group consists of basaltic lavas, autoclastic breccias or pillows (Hakkarainen, 1994), intercalated only locally with felsic rocks (Kähkönen, 2005). Metapelites are absent. The lavas are interpreted to have erupted along a linear E-trending fissure system (Hakkarainen, 1994).

Age data for metavolcanic rocks are sparse and are even lacking for the Forssa Group metavolcanic rocks. A dacitic rock sample in the Koijärvi area (outside the study area) gives a U-Pb zircon age of 1888 $\pm 11 \mathrm{Ma}$ (Vaasjoki, 1994); a plagioclase porphyrite and a gabbro south of the study area have ages of $1880 \pm 3 \mathrm{Ma}$ and $1880 \pm 5 \mathrm{Ma}$, respectively (Suominen, 1988). Both rocks are correlated with the Häme Group (Kähkönen, 2005).

The main tectono-metamorphic evolution is expected to have taken place between $1.88-1.86 \mathrm{Ga}$ (Niironen, 1999; Väisänen et al., 2002). A 1.83 $1.81 \mathrm{Ga}$ late-Svecofennian high-temperature event, reaching its peak at about $1824 \pm 5 \mathrm{Ma}$ (Väisänen et al., 2002) led to local migmatization of the units, in particular in the granite-migmatite zone of the Uusimaa belt further south.

Two sets of respectively SW-NE- to W-E- and NW-SE-trending shear zones control the overall geometry of this area (Fig. 2). The most prominent of the latter set is the major Painio-Hirsjärvi shear zone (Mäkelä, 1989; Hakkarainen, 1994) close to Somero. The E-W oriented shear zones are parallel to the 


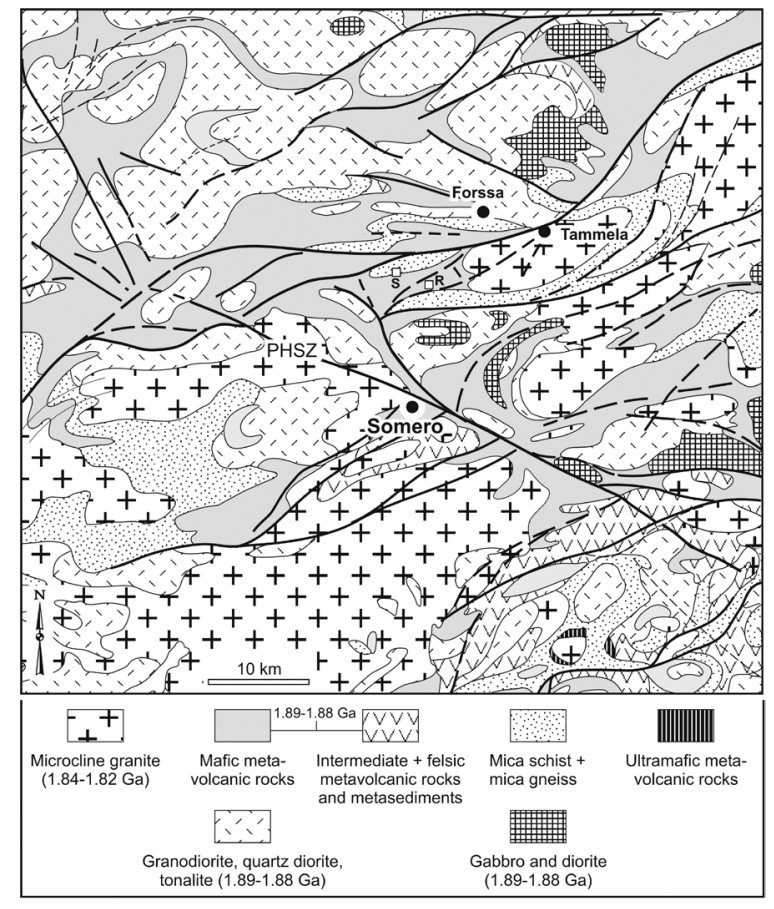

Fig. 2. a) Geological map of the Somero region. PHSZ = Painio-Hirsjärvi shear zone. " $S$ " und "R" label the Satulinmäki and Riukka prospects southwest of Forssa town. b) Tectonic map of the same area showing fault lines and different fold generations.

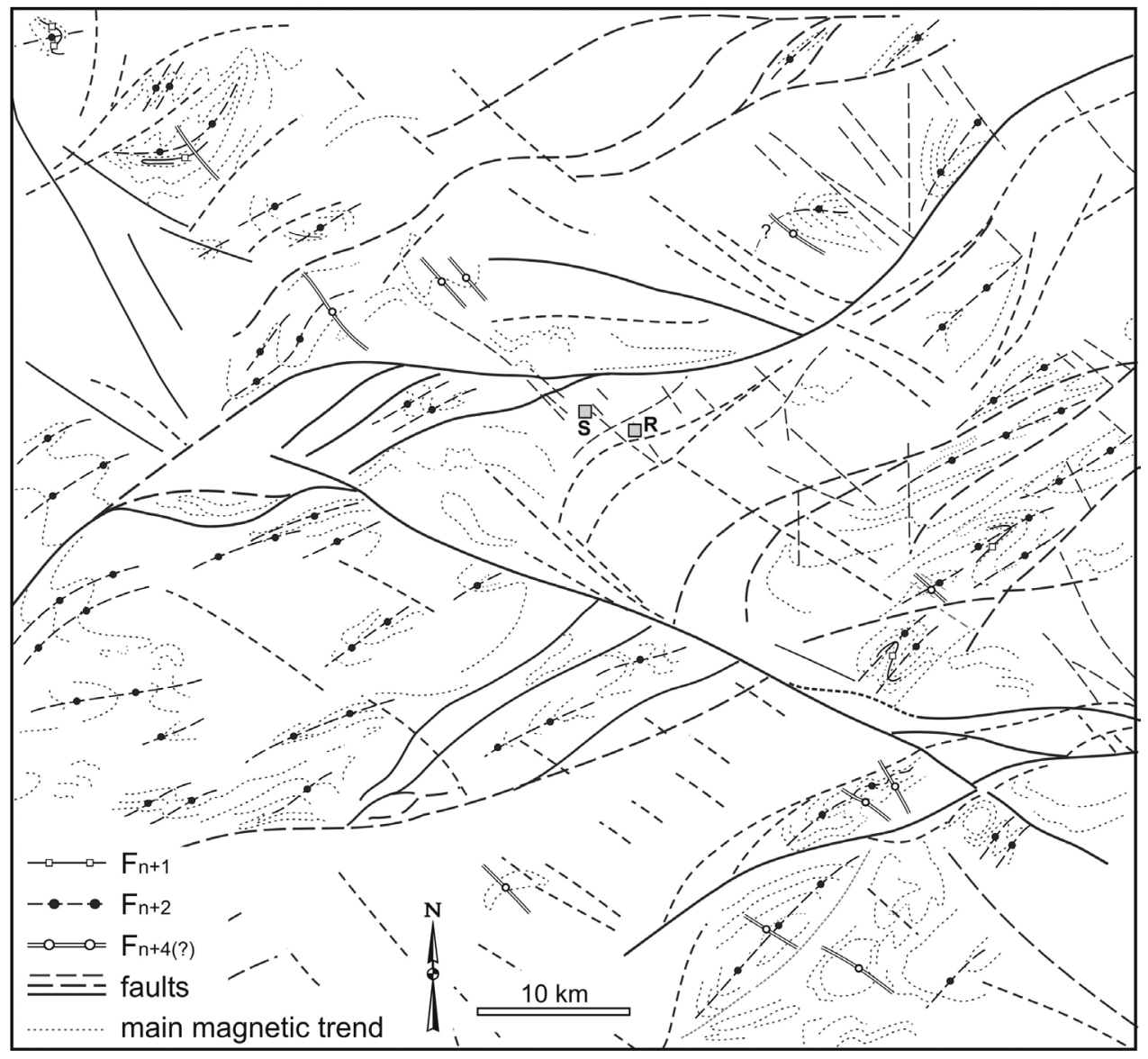




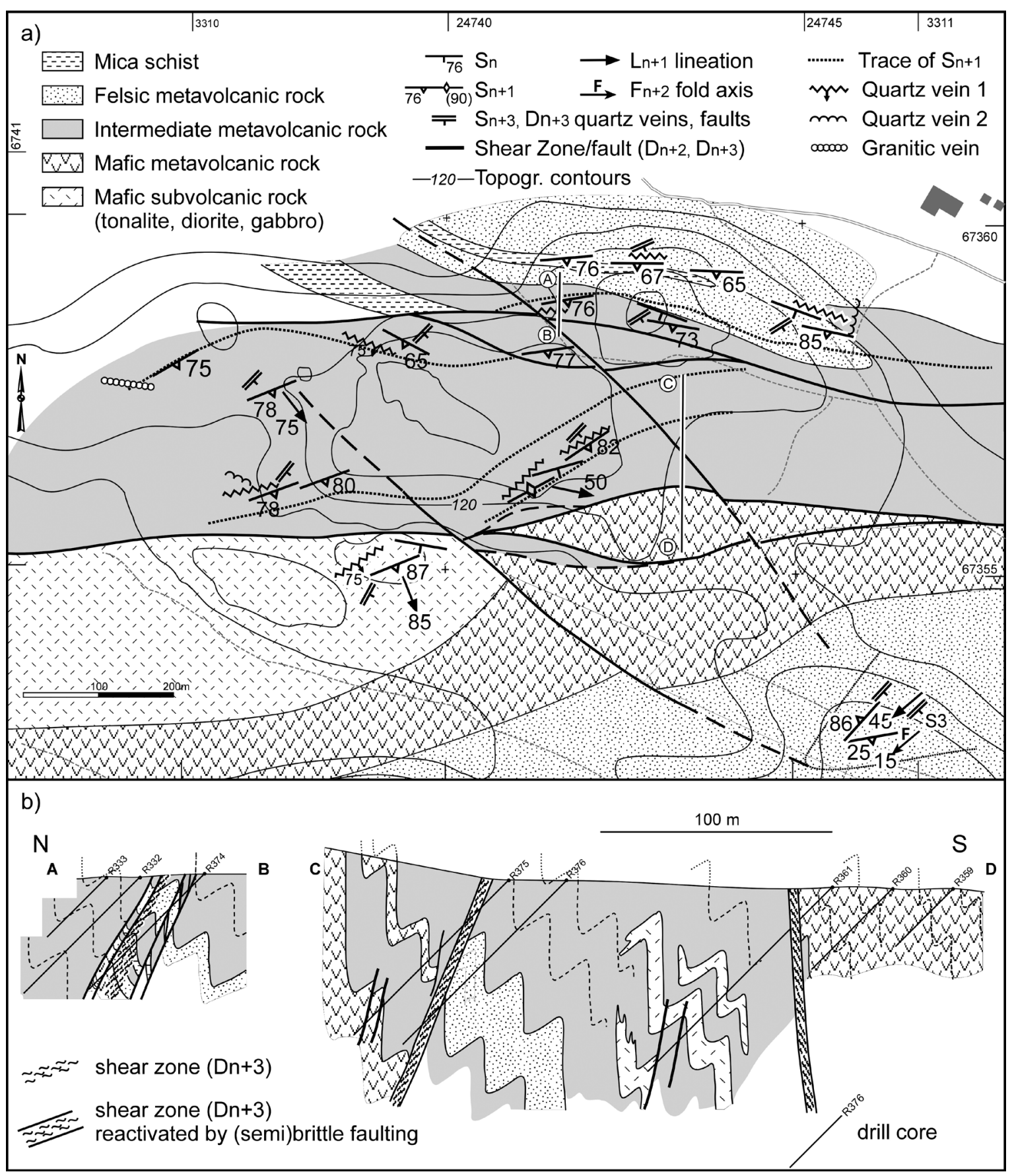

Fig.3. Geological map (a) and cross section (b) of the Riukka prospect. 


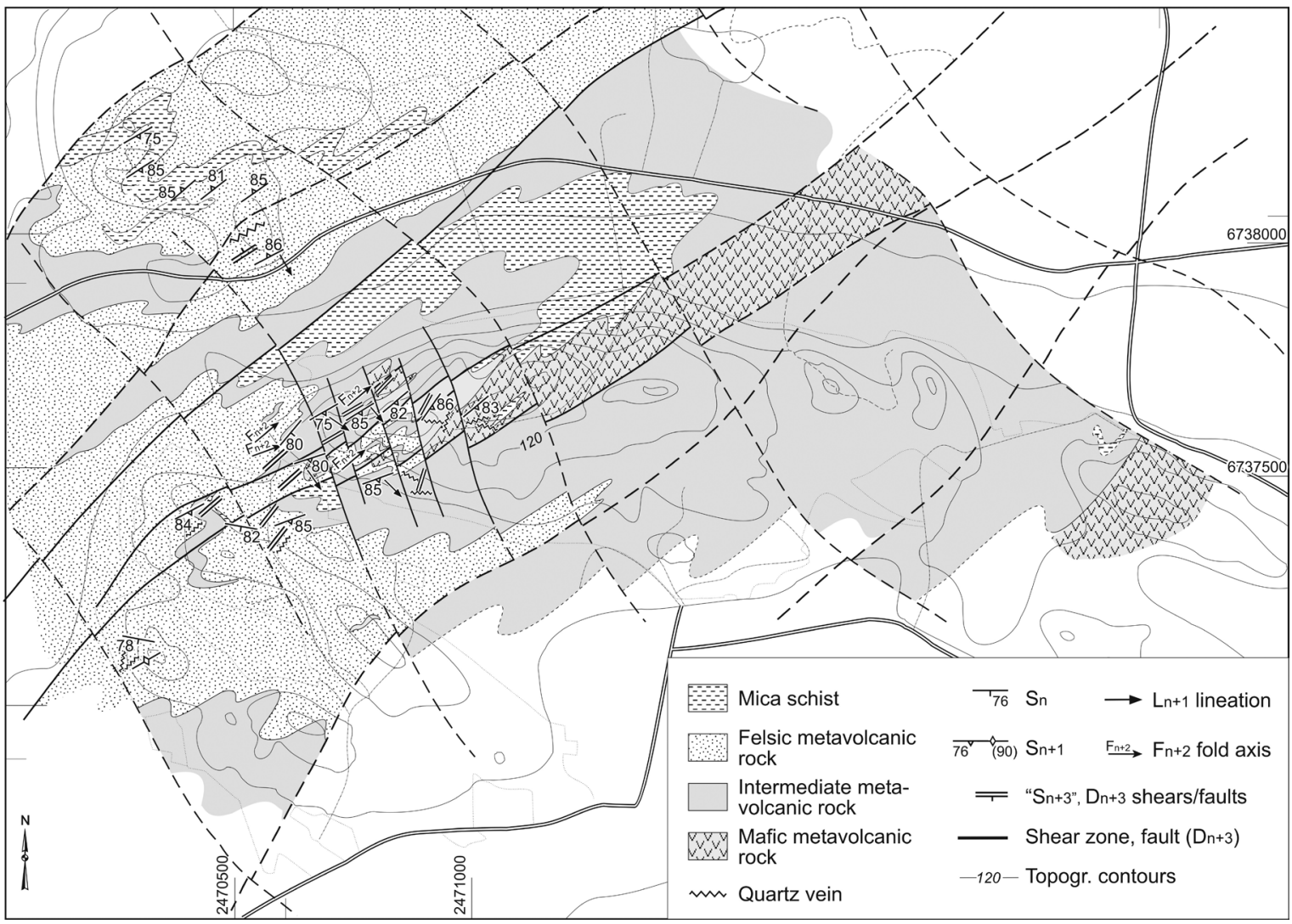

Fig. 4. Geological map of the Satulinmäki prospect.

Hämeenlinna shear zone (Hakkarainen, 1994) located north of the map area of Fig. 2.

\section{Geological overview of the Satu- linmäki and Riukka gold prospects}

The Somero-Tammela gold critical zone south of Forssa comprises calc-alkaline metavolcanic and metasedimentary rocks of the Forssa Group. Two gold prospects, Riukka and Satulinmäki, are exposed $12-17$ $\mathrm{km}$ southwest of Forssa.

The host rocks of the gold prospects are deformed and metamorphosed mafic to felsic volcanic and pyroclastic rocks. Metavolcanic rocks clearly dominate the lithology in this area. The portion of felsic rocks and metasedimentary rocks increases to the $\mathrm{N}$ and NW. Many fine- to medium-grained felsic and intermediate volcanic rocks are pyroclastic rocks like tuffs and tuffaceous rocks. Some layers of agglomeratic character occur, but are less frequent than in areas north of the two propects. The layering is defined by composition and grain size. Some rocks very likely represent lavas; very coarse-grained, mafic granoblastic rocks are interpreted as subvolcanic rocks rather than plutonic bodies. They consist mainly of plagioclase and hornblende and locally resemble gabbroic rocks. This group includes so-called uralite porphyry, coarse-grained to porphyritic mafic metavolcanic rocks, which occur predominantly in the southern part of the Riukka prospect. Some felsic quartz-feldspar rocks may represent felsic dykes. Metasedimentary rocks are mica schists and mica gneisses, mainly composed of quartz, plagioclase, biotite and muscovite. Some schists contain andalusite porphyroblasts. Quartz-feldspar schists contain quartz, plagioclase, locally microcline and biotite. Despite an amphibo- 


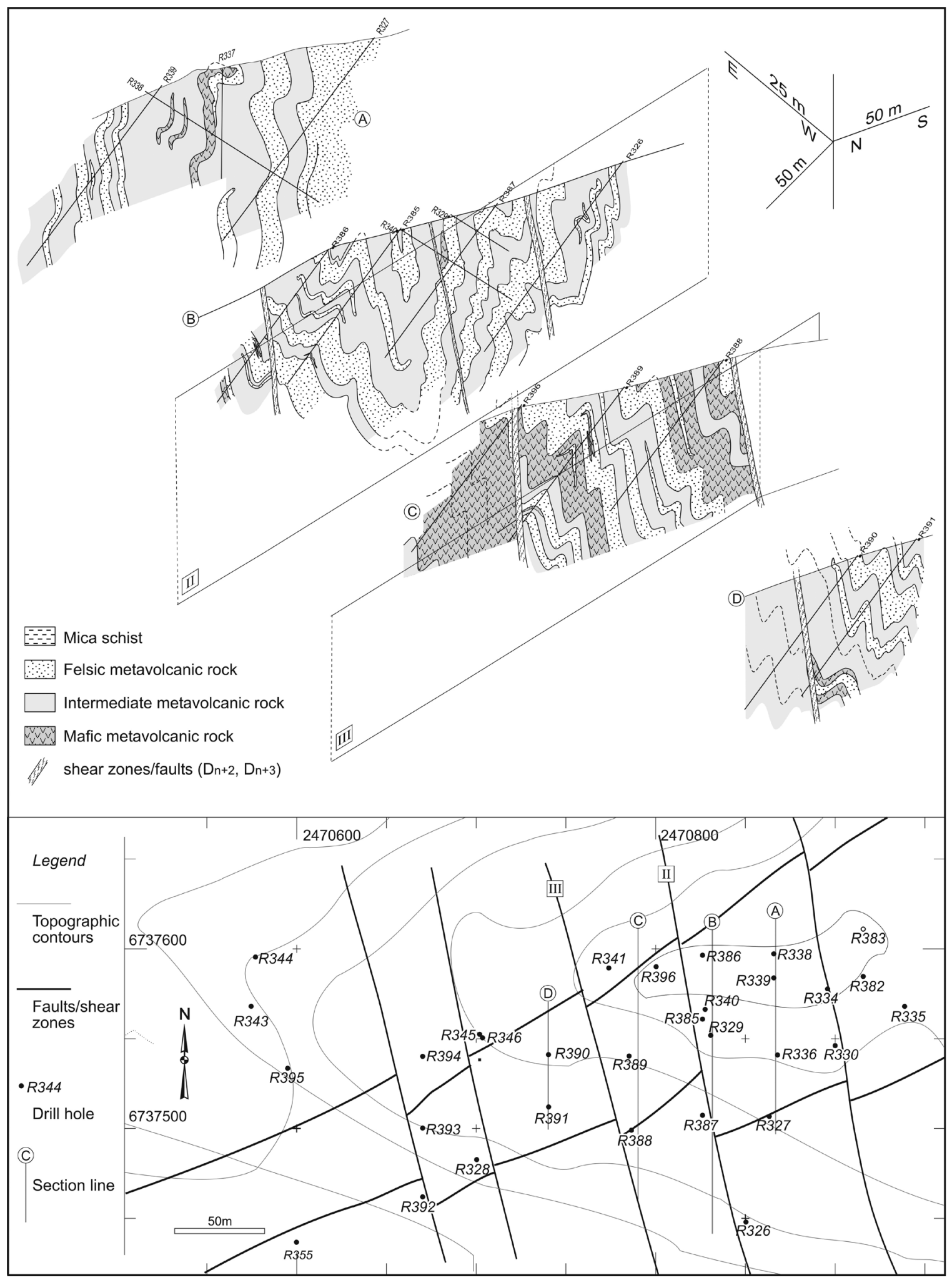

Fig. 5. Cross sections and plan view of the Satulinmäki prospect showing the main lithologies, main structures and folding style. Cross sections are based mainly on drill core data (locations of sections are marked in the map). 


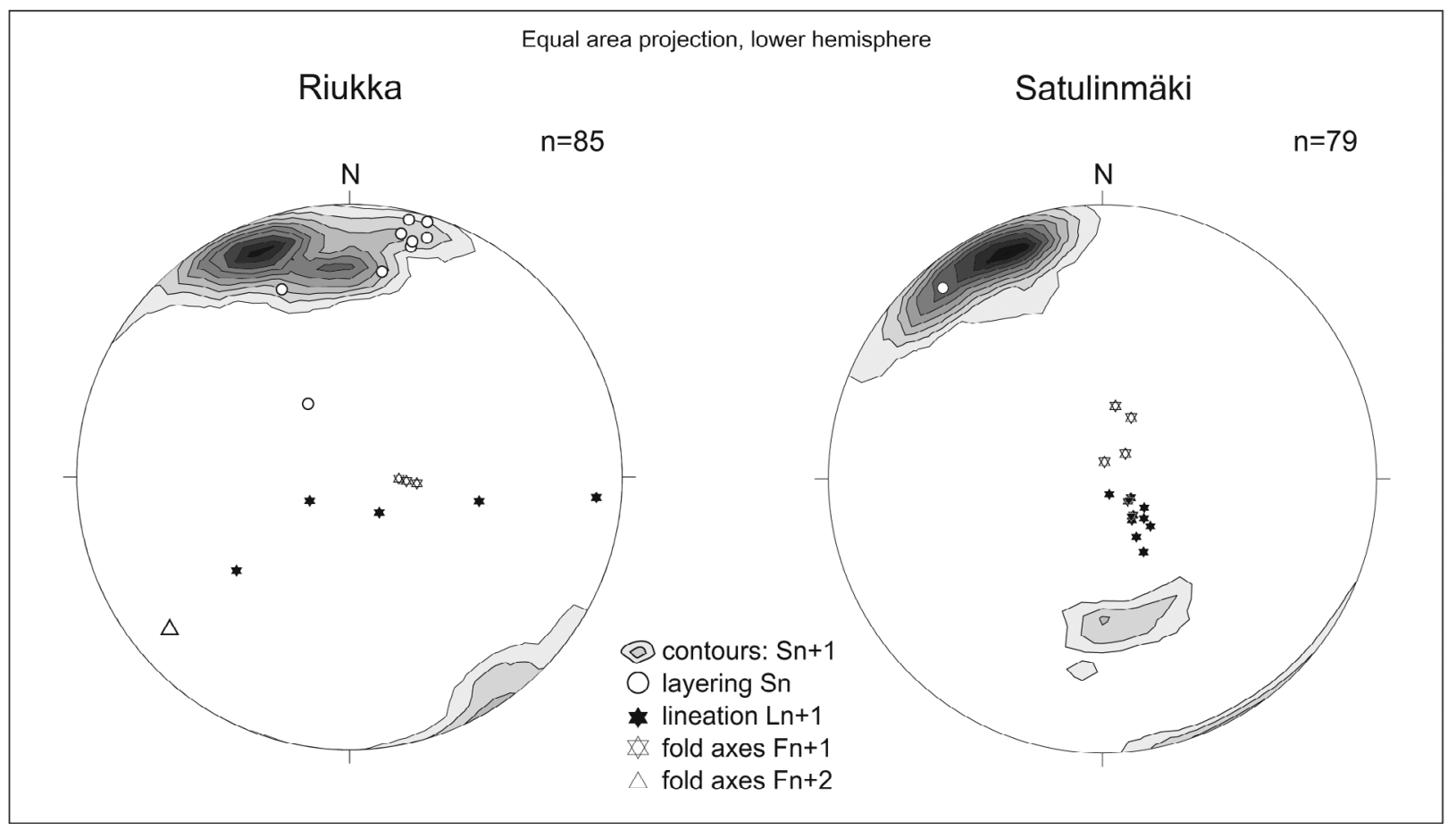

Fig. 6. Stereoplots of structural elements in the Riukka and Satulinmäki prospects (equal area lower hemisphere projection).

lite facies metamorphic overprint primary sedimentary structures like cross bedding are locally preserved in the tuffaceous and metasedimentary rocks.

Granodiorites, tonalites and quartz diorites intrude into the metavolcano-sedimentary rocks. Some gabbroic to dioritic and tonalitic rocks in the prospect areas very likely represent subvolcanic dykes or sills. The quartz diorites have typically hypidiomorphic textures, but they are also foliated. This foliation is developed to a varying degree, with the marginal portions of the intrusions being better foliated. Foliation planes are defined by a \pm diffuse layering of feldspar-rich and amphibole/biotite rich layers as well as by the shape-preferred orientation of amphibole aggregates and biotite. Mafic enclaves and xenoliths are locally aligned parallel to the foliation as well. In thin sections, the foliation is less obvious and mainly defined by a weak compositional layering as well as few mineral grains aligned parallel to the layering. Within the layers, feldspar and amphibole crystals are mostly randomly oriented. The foliation dips to the SE and is therefore parallel to $S_{n+1}$ in the schists and gneisses.

Granitic rocks are widespread in the region but are not exposed in the Satulinmäki and Riukka gold prospects, except of a quartz-feldspar dyke, partly pegmatitic, and local thin granitic dykes in the southern and western parts of Riukka. Whether the dykes are genetically linked to large late-tectonic granites bodies outside the prospects remains unresolved.

The area is cut by a number of shear zones and faults. Most strike SW-NE to WSW-ENE, a second major set consists of NW-SE-striking faults (Fig 2). The Satulinmäki and Riukka gold prospects are located at second and third order shear zones and faults parallel to the major NW-SE and SW-NE to W-E oriented lineaments (Fig. 2). The two fault and shear sets are also developed on prospect- and outcrop-scale (Fig. 3, 4). The overall geometry and map-scale faults in both prospects are to a great part determined by 3D modelling with the help of drill cores; aeromagnetic maps are especially useful in this area for locating faults. 


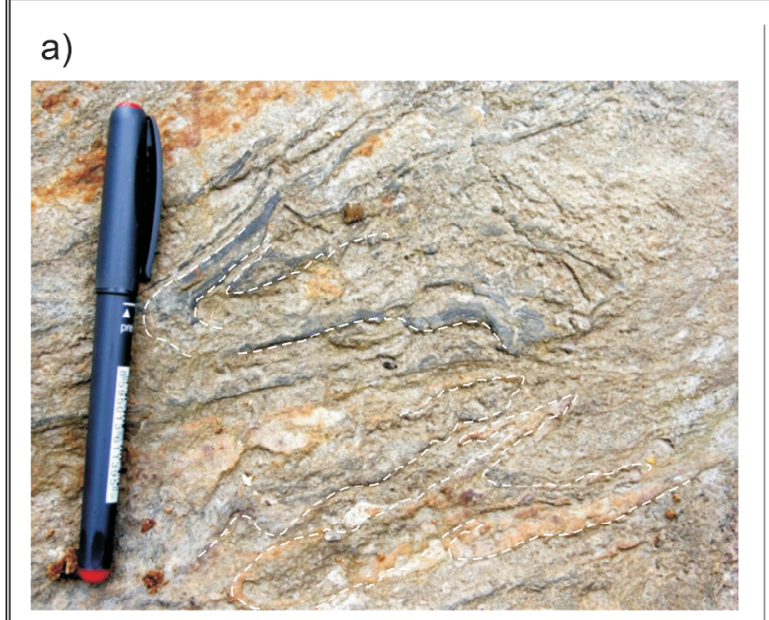

b)
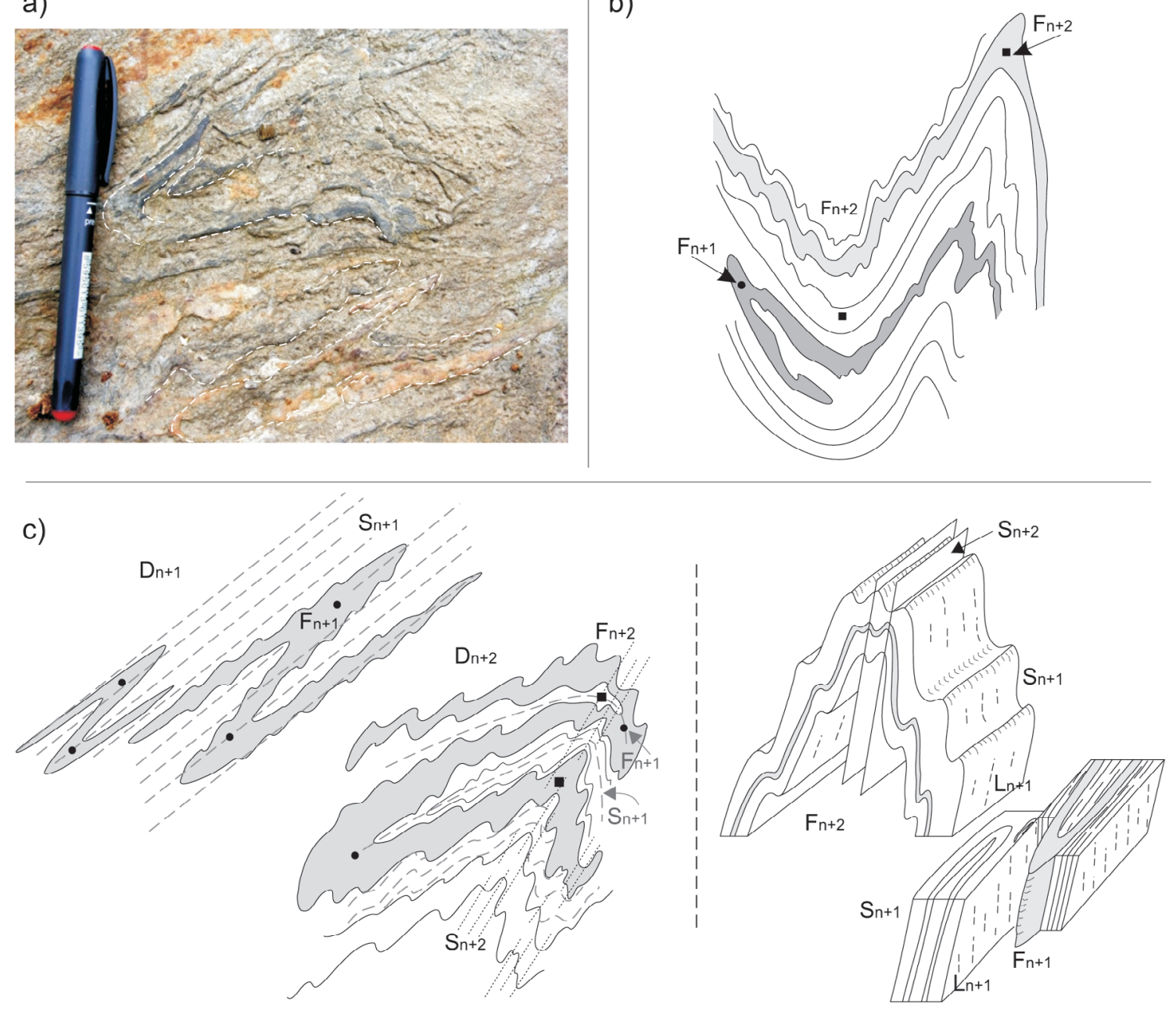

d)
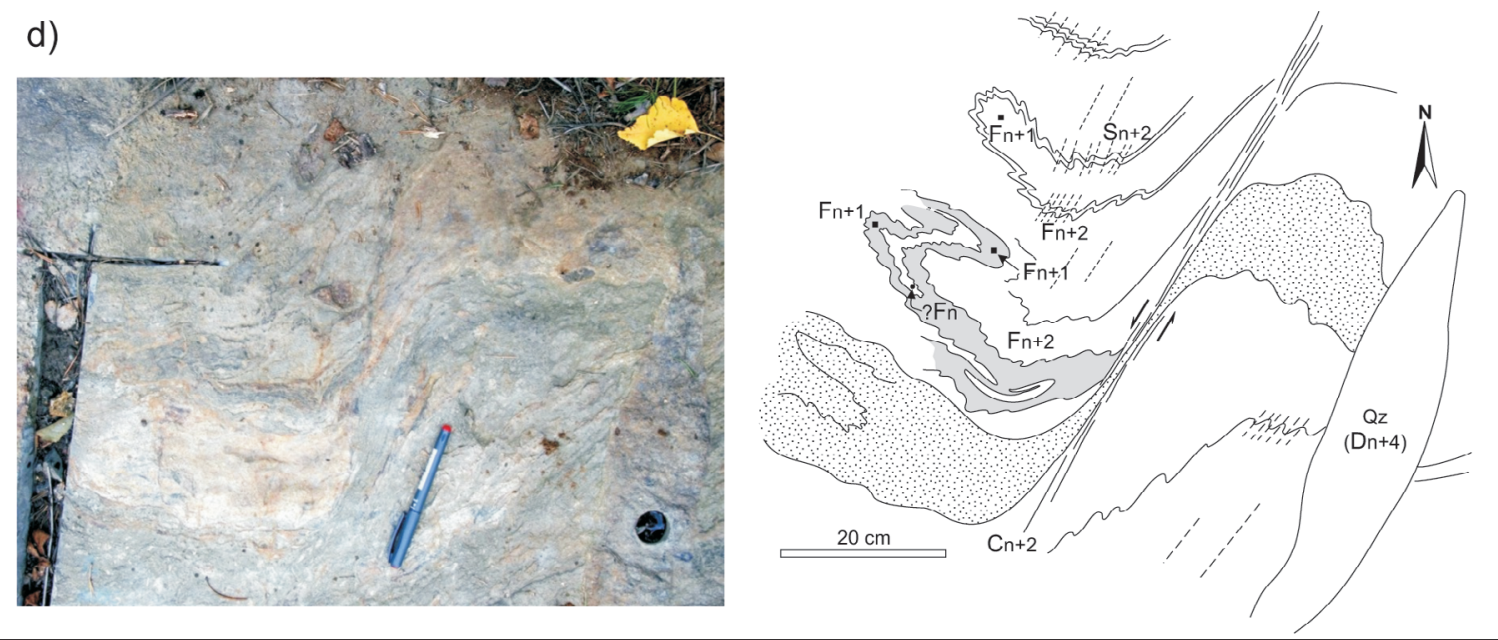

Fig. 7. a) $F_{n+1}$ closed to isoclinal folds of layering $S_{n}$ (Satulinmäki). Scale (pen length) $=13.5 \mathrm{~cm}$. b) Outcrop sketch of fold interference of $F_{n+2}$ refolding $F_{n+1}$ isoclinal folds (Satulinmäki). c) Schematic sketch illustrating the series of fold generations and foliation development during $D_{n+1}$ and $D_{n+2}$ as well as the geometric relationship of $F_{n+1}$ and $F_{n+2}$. $d$ ) $F_{n+2}$ folding associated with shearing $\left(C_{n+2}\right)$ (Satulinmäki). Scale in photo (pen length) $=13.5 \mathrm{~cm}$ 
The southern part of the Riukka prospect is dominated by mafic metavolcanic rocks (uralite porphyry), bordered to the north by intermediate metavolcanic rocks, which are followed by more felsic rocks in the northernmost area (Fig. 3). Nearly E-W-trending faults are cut by NW-SE striking faults. Likewise, the overall structure of the Satulinmäki prospect is characterized by a map-scale fold structure that is cut by major SW-NE shear zones and faults as well as NW-SE faults (Fig. 4, 5). The dominant foliation is subvertical or dips steeply to the SE or NW and the trend of map-scale fold axes varies between SW-NE and W-E (Fig. 6).

\section{Structural evolution}

A number of deformations can be distinguished; however, it is important to note that different phases do not necessarily represent temporally separated events but might be transitional and belong to one single deformation episode. For example, $\mathrm{D}_{\mathrm{n}+2}$ and $\mathrm{D}_{\mathrm{n}+3}$ might represent increments of a single major deformational event, like a collisional or accretional event, reflecting progressive deformation at varying metamorphic degrees and kinematics. Therefore, two subsequent phases might be transitional with only a slight shift to different conditions (e.g. varying stress field or crustal level). Nevertheless, they represent increments or distinct phases that can be distinguished by their structures (as is, for example, the case for $D_{n+2}$ and $\mathrm{D}_{\mathrm{n}+3}$, see below). On the other hand, as will be shown with $\mathrm{D}_{\mathrm{n}+3}$, single phases might represent longlasting events comprising both ductile and brittle deformation as well as several episodes of fault reacti- vation. Hence, the indication of $D_{n}$ to $D_{n+x}$ is used in the sense that distinct deformation phases and related structures can be recognized and separated in terms of their fabrics, timing by overprinting relationships, kinematics, and possibly also metamorphic grade. They are not regarded in the way that every single phase represents a single orogenic event.

\section{I. $D_{n}$}

It is not unequivocal whether the compositional layering in the pyroclastic rocks represents the primary layering (e.g. bedding in tuffaceous rocks) or a first foliation. Most layers are lens-shaped and some might represent isoclinal folds. Traces of inclusions in andalusite porphyroblasts $\left(S_{\mathrm{i}}\right)$ in mica schist are parallel to an external foliation $\left(\mathrm{S}_{\mathrm{e}}\right)$ but are more spaced and the internal foliation is less intense. They might indicate either an earlier foliation with the external forming parallel to it or $S_{i}$ and $S_{e}$ represent different stages of a single foliation development. Sericite is aligned in the fold hinges of supposed $\mathrm{F}_{\mathrm{n}+1}$ folds would indicate the existence of an older foliation as well. Likewise, narrow quartz veins parallel to the layering might have formed during development of an early foliation. On the other hand, primary volcanic and sedimentary structures are well preserved, especially in areas north of Forssa. Therefore, since the preservation of bedding planes $S_{0}$ and the existence of an early foliation remain unsolved, the neutral label $S_{n}$ is chosen here for the compositional layering. Consequently, subsequent deformations and foliations are named respectively $\mathrm{D}_{\mathrm{n}+1}, \mathrm{D}_{\mathrm{n}+2}$ and $\mathrm{S}_{\mathrm{n}+1}, \mathrm{~S}_{\mathrm{n}+2}$ etc.

Fig. 8. a) W-E trending $D_{n+3}$ quartz tourmaline vein in the southern parts of the Riukka prospect cutting the dominant $S_{n+1}$ foliation at acute angle. The sheared margin indicates a dextral component of shear during emplacement. Scale (compass) $=7.5 \mathrm{~cm}$; photo in upper right corner: coin diameter $=2.1 \mathrm{~cm} . \mathrm{b}$ ) WSW-ENE oriented dextral $D_{n+3}$ shear zone in Satulinmäki. c) $D_{n+3}$ discrete brittle faults and thin quartz veins in Satulinmäki indicating $\sim W N W$ ESE dextral transpression. The faults are accompanied by thin quartz filled tension gashes (partly en echelon). Scale (sharpener) $=2.5 \mathrm{~cm}$. d) Felsic metatuff or tuffaceous rock in the Riukka prospect with penetrative $S_{n+1}$ foliation. Later NE-SW-striking thin quartz veins and fracture planes are inclined to the foliation and represent $S_{n+3}$. Scale (coin diameter) $=1.9 \mathrm{~cm}$. e) Dextral $D_{n+3}$ faults in southern part of the Satulinmäki prospect. Note that dextral displacement is not coherent but heterogeneous along a single fault suggesting oblique dip slip rather than mainly lateral displacement. Scale (compass) $=7.5 \mathrm{~cm}$ 

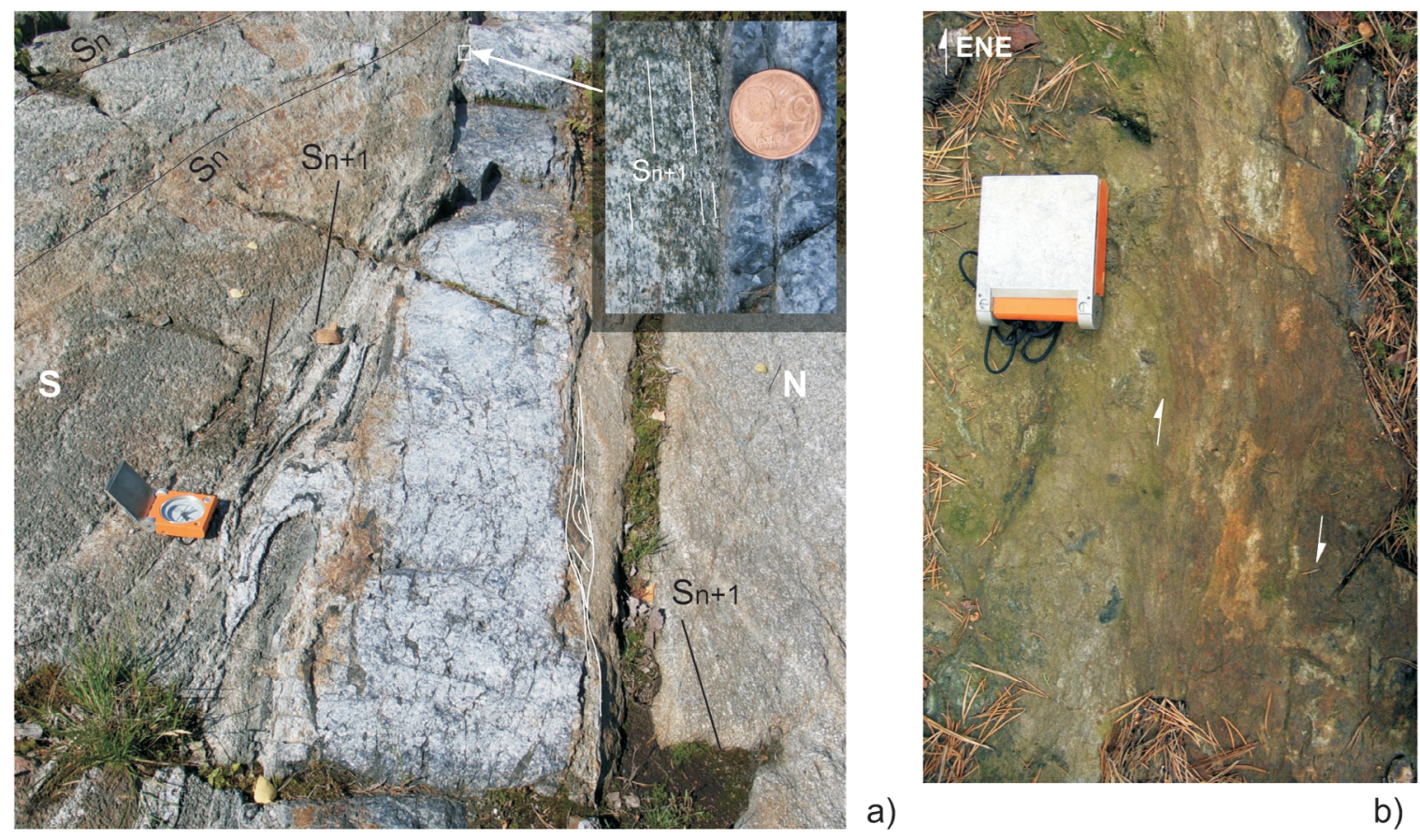

a)

b)
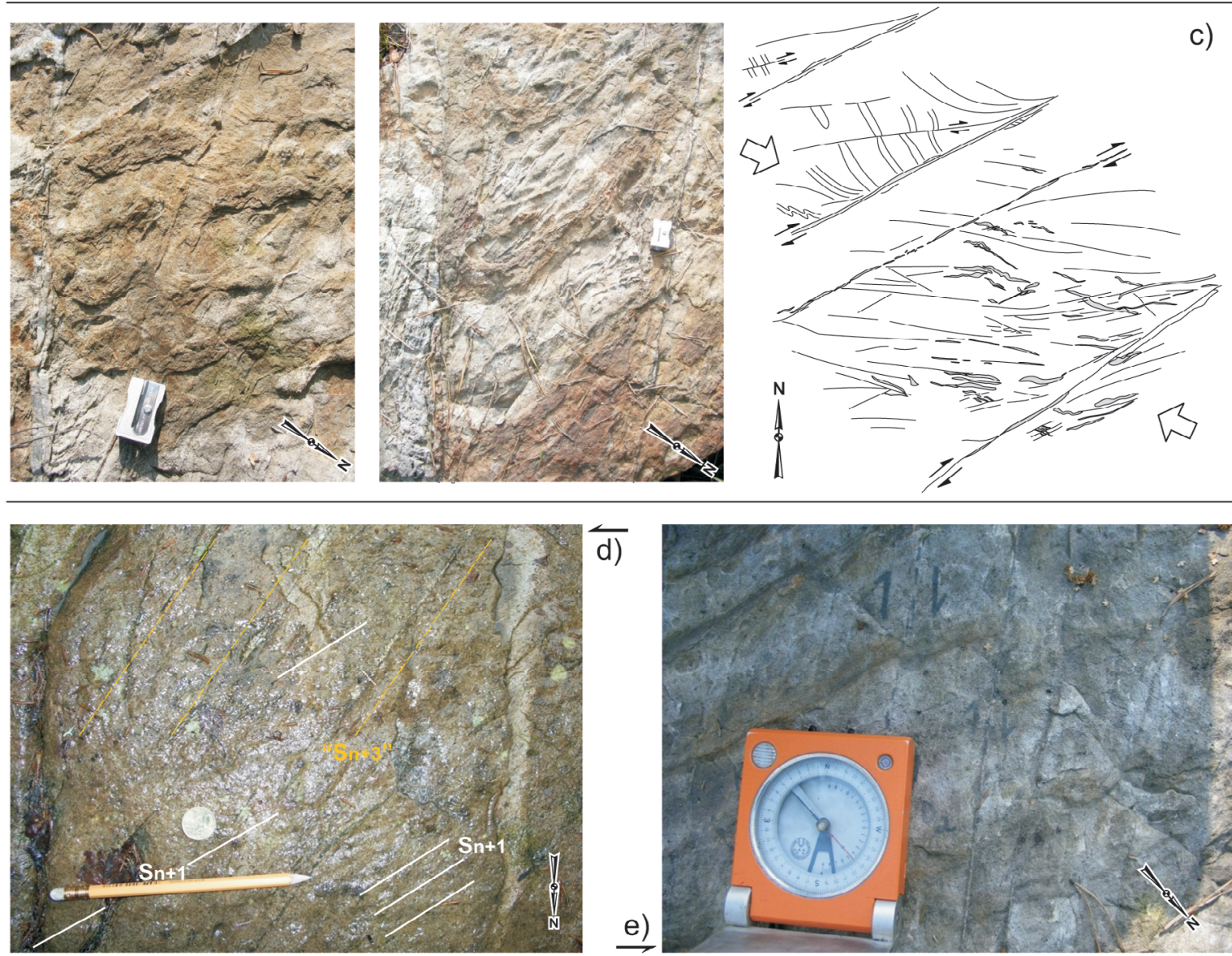


\section{2. $D_{n+1}$}

$\mathrm{S}_{\mathrm{n}+1}$ represents the dominant penetrative foliation in the area and developed parallel to the layering since it formed as an axial planar foliation to iscolinal folds $F_{n+1}$ of the layering $S_{n}$. On outcrop-scale, $F_{n+1}$ folds are preserved in a cm- to dm-scale (Fig. 7a). A subvertical SSE-plunging stretching and mineral lineation, $\mathrm{L}_{\mathrm{n}+1}$, is parallel to the $\mathrm{F}_{\mathrm{n}+1}$ fold axes. $\mathrm{S}_{\mathrm{n}+1}$ is defined by the shape-preferred orientation of biotite, amphibole and, in felsic rocks, fine-grained muscovite. Isoclinally folded quartz veins occur parallel to the foliation.

A locally developed weak mylonitic fabric suggests that $\mathrm{F}_{\mathrm{n}+1}$ folding was associated with ductile shearing, possibly in relation to early thrusting, which, considering the steeply SE- to SSE-plunging $\mathrm{L}_{\mathrm{n}+1}$ lineation, was directed to the NW to NNW. An alignment of feldspar crystals oblique to the foliation within a granodiorite corroborates a top-NW sense of shear in these rocks.

$\mathrm{D}_{\mathrm{n}+1}$ took place at the metamorphic peak reaching lower amphibolite facies conditions.

\section{3. $D_{n+2}$}

$\mathrm{D}_{\mathrm{n}+2}$ is characterized by small-scale to regional-scale folding leading to refolding of $F_{n+1}$ folds (Fig. 7). $F_{n+2}$ axial planes are steep and strike -SW-NE. During this deformation phase the map-scale folds have been formed, which together with later shear zones and faults (see below) represent the dominant structural features in the area (Fig. 2). $F_{n+2}$ axial planes are subvertical and trend - SW-NE. An axial planar cleavage, $\mathrm{S}_{\mathrm{n}+2}$, is not penetrative but restricted to the fold hinges (Fig. 7) or to more closely folded areas. Sheared limbs of some $\mathrm{F}_{\mathrm{n}+2}$ folds suggest that folding was locally associated or directly followed by SW-NE shearing $\left(\mathrm{C}_{\mathrm{n}+2}\right.$, Fig. $\left.7 \mathrm{~d}\right)$. Although this is a local and minor phenomenon observed on outcrop scale, it is likely that during the NW-SE directed contraction regional-scale $\mathrm{F}_{\mathrm{n}+2}$ folding was accompanied by thrusting. During progressive folding and shortening, folds may have been disrupted and displaced by thrust zones or faults.

\section{4. $D_{n+3}$}

The regional-scale $\mathrm{F}_{\mathrm{n}+2}$ folds are cut by major shear zones and faults formed as the result of $\mathrm{D}_{\mathrm{n}+3}$ shearing (Fig. 2, 4). Two sets of respectively SW-NE- to WSW-ENE- and NW-SE-striking shear zones and faults are developed and the pattern suggests dextral transpression. In addition to a dextral strike-slip sense of shear the fault displacement comprises a dipslip component. $\mathrm{D}_{\mathrm{n}+3}$ deformation was more localized than the earlier $\mathrm{D}_{\mathrm{n}+1}$ and $\mathrm{D}_{\mathrm{n}+2}$ and took place during retrograde metamorphic conditions at the brittle-ductile boundary. Nevertheless, the transition between $\mathrm{D}_{\mathrm{n}+2}$ and $\mathrm{D}_{\mathrm{n}+3}$ was gradual and transpression might have started already during the later stages of $\mathrm{D}_{\mathrm{n}+2}$. Some shear zones seem to have been affected by $\mathrm{F}_{\mathrm{n}+2}$ folding so that shearing started already during $\mathrm{D}_{\mathrm{n}+2}$. The main difference between $\mathrm{D}_{\mathrm{n}+2}$ and $\mathrm{D}_{\mathrm{n}+3}$ is that the former is characterized more by folding whereas shear deformation and localization of deformation became more important during $\mathrm{D}_{\mathrm{n}+3}$. A welldefined temporal boundary between the two phases does not exist.

Many quartz veins in Riukka and Satulinmäki are interpreted to have formed during this deformational phase. Quartz veins are in places accompanied by sulphidization of the wall rock. Fig. 8a shows an example of a WSW-ENE oriented quartz-tourmaline vein cutting dioritic porphyry rocks in southern parts of the Riukka prospect. The vein cuts the $S_{n+1}$ foliation at an acute angle. The margin is sheared, and accompanying thinner quartz veins are folded. The wall rocks of many quartz veins show a strong foliation parallel to the quartz vein margins (Figs. 10a, b), commonly containing sulphide minerals aligned in the foliation. Biotite and amphibole (actinolite) define the foliation and show a strong shape-preferred orientation in addition to minerals growing in interstitial sites that may show a more random orientation (Figs. 10e, f). The microfabrics of the quartz veins points to deformation at low temperatures. The quartz grains show an undulose and patchy extinction and serrate grain boundaries. In some veins, recrystallized small-scale bulges occur at the grain boundaries 


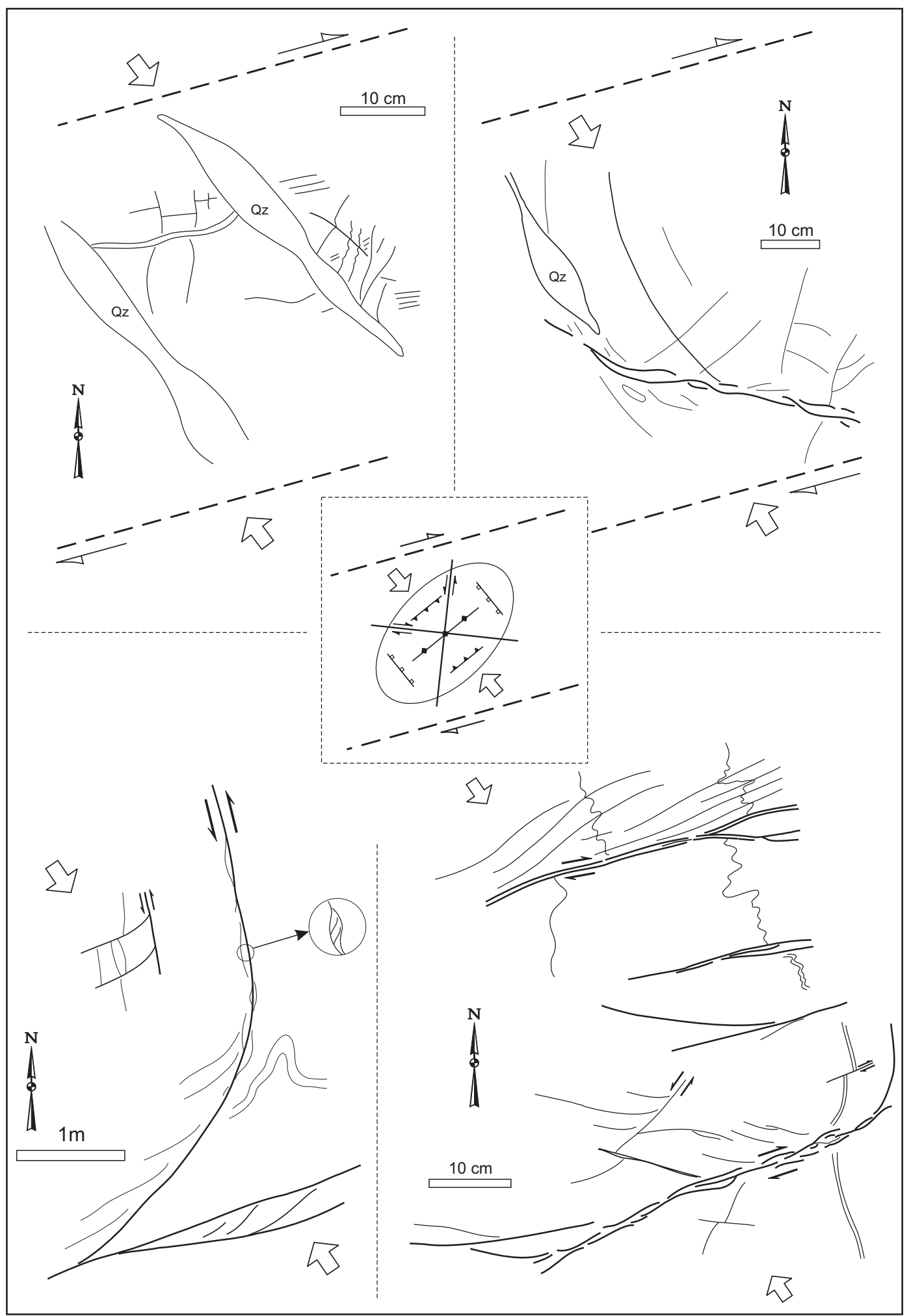

Fig. 9. Outcrop field sketches of faults, fractures and quartz veins in Riukka and Satulinmäki prospects post-dating $F_{n+2}$ folding. The patterns indicate dextral transpression with $\sigma \mathrm{I}=\mathrm{WNW}$-ESE to NW-SE (stress ellipse in centre). These brittle faults and veins represent deformation typical for $D_{n+3 b}$. 


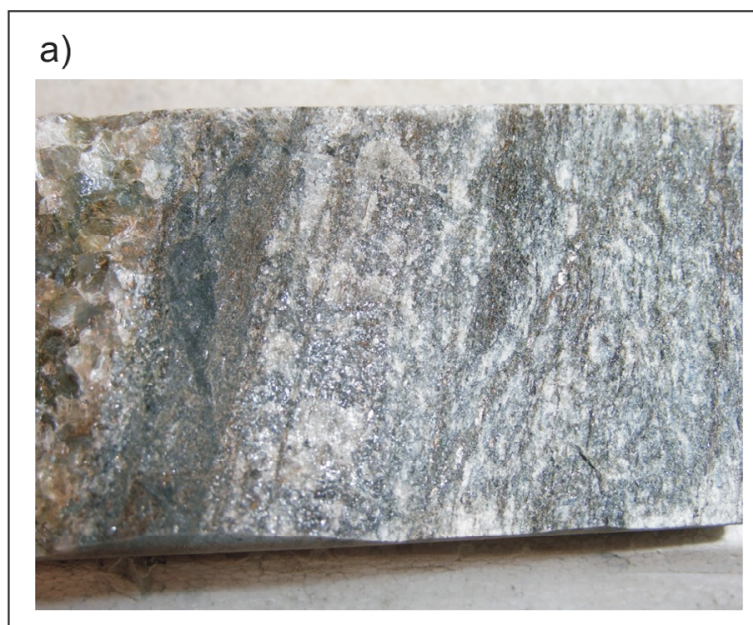

b)

c)

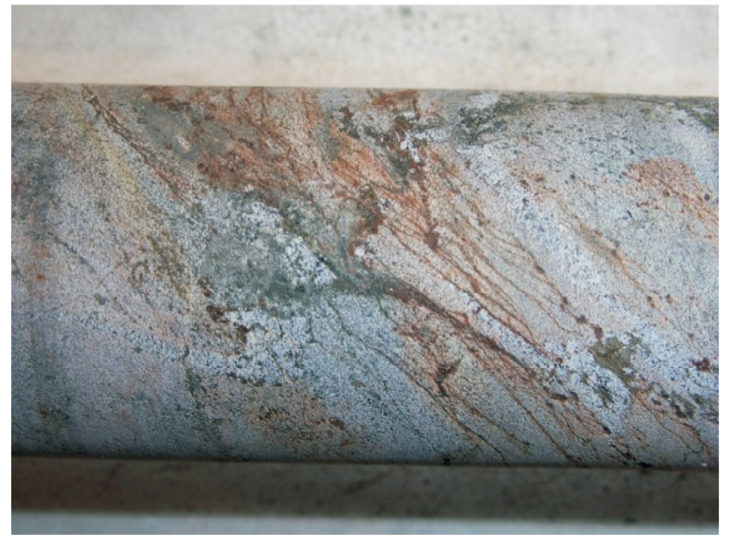

e)

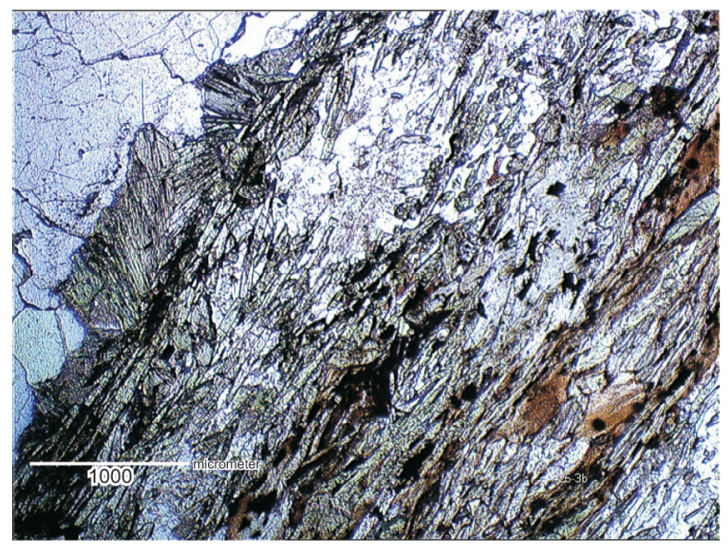

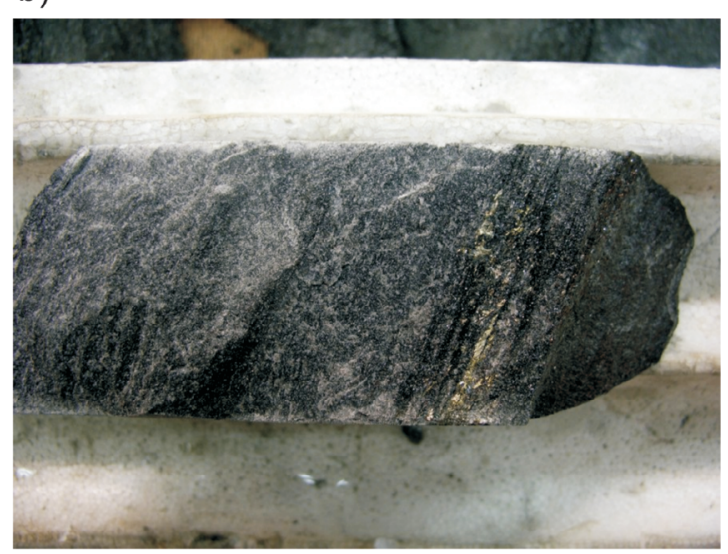

d)

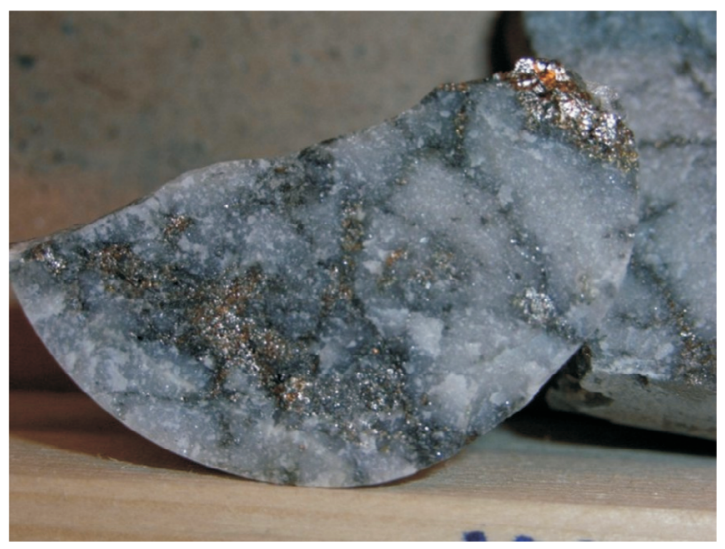

f)

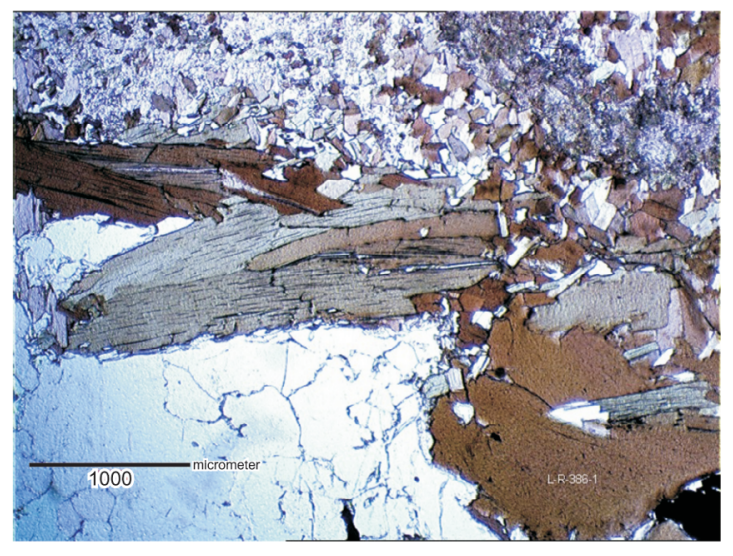

Fig. 10. Photographs showing mineralization related to textures in drill core and thin sections. a) Syn-D ${ }_{n+3}$ quartz vein containing tourmaline, sulphide minerals and local biotite surrounded by parallel $D_{n+3}$ shear zones in a drill core (Riukka). b) Example of mineralization in a drill core sample of silicified mica schist (Riukka). Sulphide minerals, tourmaline and biotite precipitated along $S_{n+3}$ shear foliation in a $D_{n+3}$ shear zone. c) Brittle $D_{n+3}$ shear zone in drill core (Riukka). d) Sulphide mineralization in a quartz vein (drill core sample, Satulinmäki). e) Photomicrograph of intermediate to mafic metavolcanic rock cut by a syn- $D_{n+3}$ quartz vein in a shear zone (Riukka). Strongly aligned biotite and amphibole occur in the sheared margin of the quartz vein. Amphibole also grows directly at the irregular quartz vein margin. f) Photomicrograph of biotite at the margin of a quartz vein that cuts fine-grained, intermediate metavolcanic host rock (drill core sample, Satulinmäki). 
Table I. Table summarizing deformation phases $D_{n}-D_{n+4}$ and related structures. Mineralization took place during $D_{n+3}$ dextral transpression, but might have started already during the late stages of $D_{n+2}$.

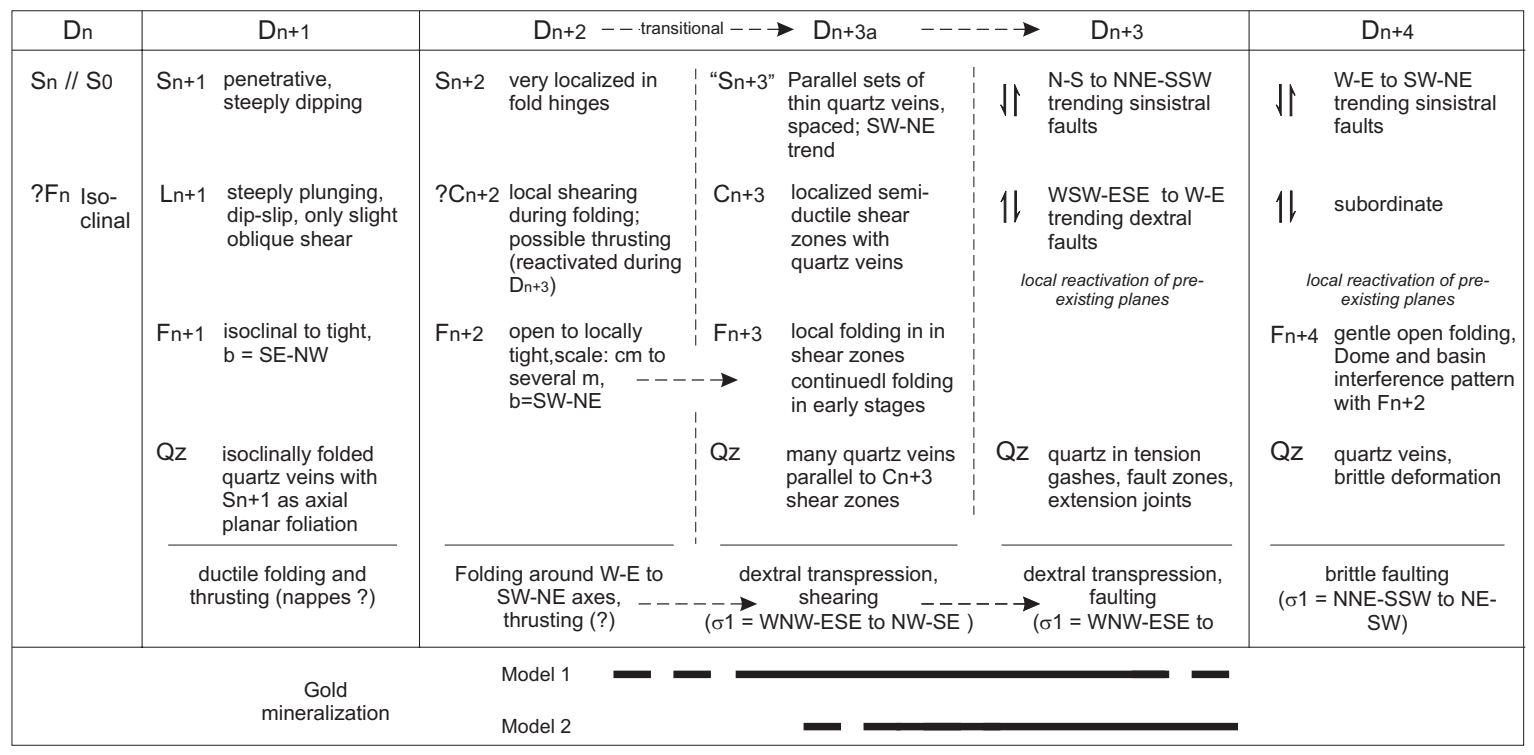

and in cracks. This indicates deformation by bulging recrystallization at temperatures of about $300{ }^{\circ} \mathrm{C}$ (Stipp et al., 2002). In other veins, the quartz grains are fractured, indicative of cataclastic flow whereas crystal plasticity is limited and displayed by undulose extinction and serrate grain boundaries and only local recrystallized bulges. Temperatures forming this fabric are supposed to have been about $250^{\circ} \mathrm{C}$ (Stipp et al., 2002).

In the field, $\mathrm{D}_{\mathrm{n}+3}$ shear zones reach thicknesses from few $\mathrm{cm}$ to several metres. The latter comprise bundles of narrow anastomosing shear planes and thin quartz veins and show a shear foliation. These zones are better exposed in the Satulinmäki prospect. Shearing is commonly accompanied by alteration of the wall rocks. S-shaped shear plane patterns and curving of subordinate shear zones into the principal displacement zone indicate a dextral sense of shear along the WSW-ENE shear zones.

$\mathrm{D}_{\mathrm{n}+3}$ shear zones and fault zones are intersected in drill cores (Fig. 10) where they locally reach thicknesses up to several $\mathrm{dm}$. Bundles of semi-brittle shear bands and narrow zones of anastomosing brittle faults can both be observed. In many outcrops quartz veins are associated with conjugate sets of shear planes and faults that are brittle structures in contrast to the sheared quartz vein margins. The geometry clearly points to oblique contraction due to - WNW-ESEto NW-SE directed maximum principal stress and thus dextral transpressional stress conditions (Fig. 9). Hence, these faults and quartz veins can be attributed to $\mathrm{D}_{\mathrm{n}+3}$ as well. The difference in rheological properties within various shear zones and drill cores as well as the contrast between sheared quartz vein margins and brittle faulting along discrete planes, with all structures corresponding to the same tectonic regime and displaying the same kinematics, suggests that $\mathrm{D}_{\mathrm{n}+3}$ was a long lasting event occurring at the transition from ductile to brittle conditions during progressive deformation, e.g. due to uplift to lower crustal levels. Therefore, $\mathrm{D}_{\mathrm{n}+3}$ could be subdivided into two stages, $D_{n+3 a}$ and $D_{n+3 b}$ (Table 1). It is a quite common observation, especially in drill cores, that shear zones, shear planes and faults formed during the earlier stages have been reactivated in a more brittle style at later stages. It is, however, important to note that the rheological behaviour of the rocks is depending not only on its lithology and the temper- 


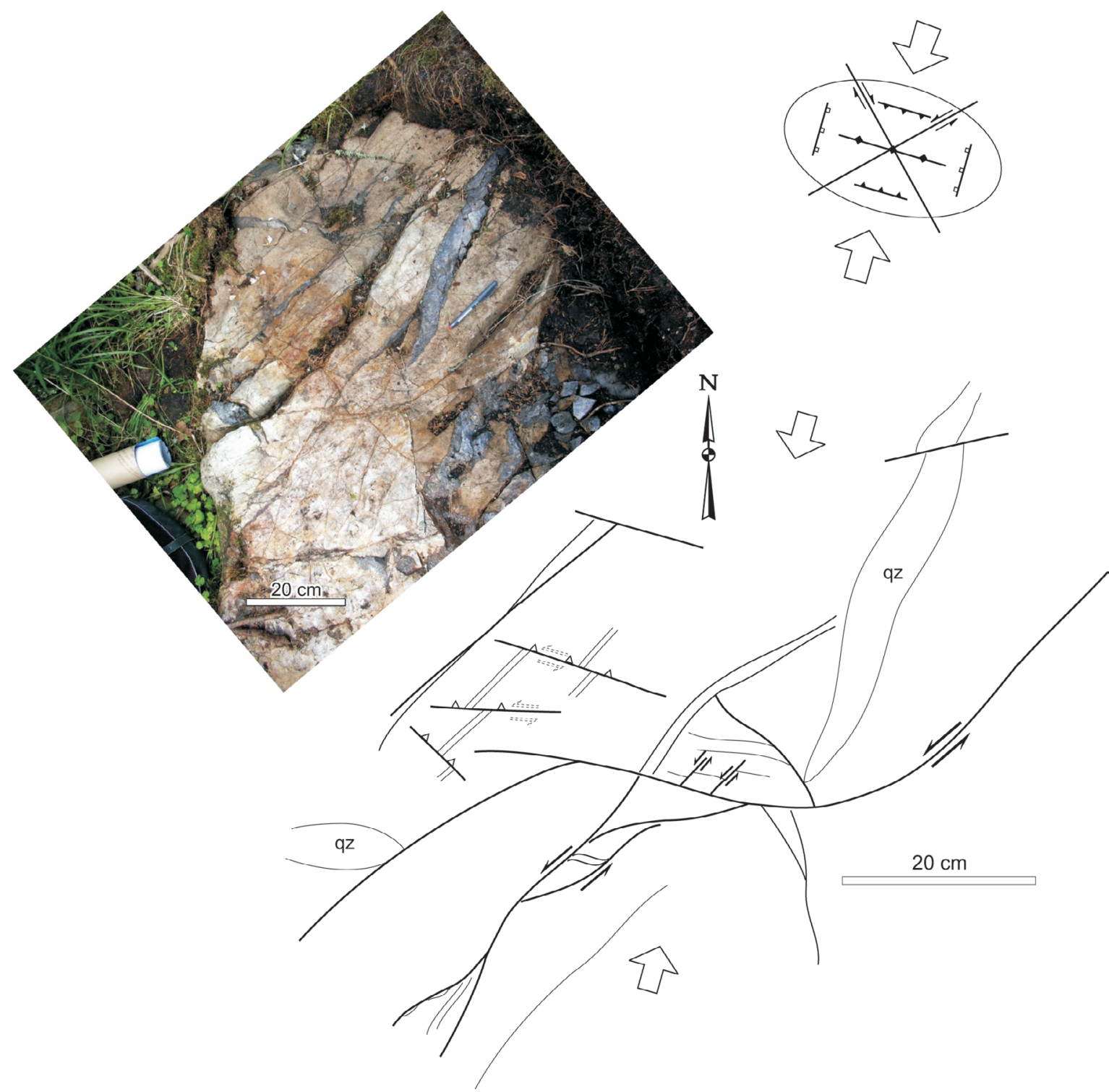

Fig. II. Photograph and field sketch of brittle sinistral faults and quartz veins that indicate a NE-SW orientation of $\sigma \mathrm{l}$ in Satulinmäki. These faults formed during $D_{n+4}$. Scale in photo (pen length) $=13.5 \mathrm{~cm}$

ature but also on lithostatic pressure (crustal level), pore fluid pressure, strain rate and differential stress values so that semi-ductile structures in one outcrop might be coeval to brittle faulting in another. Hence, the two substages of deformation are not following one another in a strict temporal order but the transition is diachronous. Simultaneous occurrence of a variety of structures ranging from (semi-)ductile shearing to brittle fracturing is typical for the brittle-ductile transition. Nevertheless, a temporal change to generally more brittle conditions during progressive $\mathrm{D}_{\mathrm{n}+3}$ seems very likely.

Apart from the development of a closed shear foliation at the $\mathrm{D}_{\mathrm{n}+3}$ shear zones or at the margins of quartz veins a penetrative $S_{n+3}$ foliation has not been developed; however, in many outcrops, especially in the Riukka prospect, a set of spaced (dm-m) parallel thin straight quartz veins, striking SW-NE, can be observed that cuts the earlier $S_{n+1}$ (Fig. 8d). The thin quartz veins as well as SW-NE-trending fractures and 
faults (Fig. 8c,e), the latter occurring especially in the Satulinmäki prospect, would correspond to a set of Splanes, $S_{n+3}$, although they are not forming a cleavage in a strict sense. In thin sections pre-existing biotite is rotated into the new S-planes. Narrow bundles of pressure solution seams are also related to $\mathrm{D}_{\mathrm{n}+3}$.

The two sets of (W)SW-(E)NE- and NW-SEtrending faults and shear zones together with $\mathrm{F}_{\mathrm{n}+2}$ folding control the overall structure of the area. The pattern can be observed from outcrop-scale to regional-scale. At the transition from $\mathrm{D}_{\mathrm{n}+2}$ to $\mathrm{D}_{\mathrm{n}+3}$ the regional stress field of approximate WNW-ESE to NW-SE compression remained, but changed to a more transpressional regime. This led to further fracturing and stacking of disrupted units. The regional thrusting direction or vergence cannot be inferred with certainty from the study area since during progressive $\mathrm{D}_{\mathrm{n}+3}$ and subsequent deformations the original geometry has been modified and partly overprinted making the reconstruction of the original orientations difficult. The observed structures nevertheless reflect the overall geometry on a smaller scale, and in the presently exposed level the shear zones and faults have sub-vertical dips to NW and SE. They show a lateral shear component that could correspond to a bivergent flower structure style. It seems likely that, in addition to formation of new steeply dipping faults and shears, possible pre-existing $\mathrm{D}_{\mathrm{n}+2}$ thrusts have been partly reactivated. Very likely the thrusts, formed during either $\mathrm{D}_{\mathrm{n}+2}$ or $\mathrm{D}_{\mathrm{n}+3}$, had sinusoid geometries with moderate to gentle dips in their upper and deeper parts (possibly bending into a major detachment).

\section{5. $D_{n+4}$}

The prospect areas are truncated by numerous faults and quartz veins that do not fit into a stress field with WNW-ESE oriented $\sigma 1$. In both prospects, various faults and conjugate sets of shear planes can be observed that could be attributed to stress variability, which is a common feature associated to brittle deformation, and the majority of late faults and shear planes correspond to WNW-ESE oriented $\sigma 1$. Some of them, however, indicate a rotation of the stress field from a - WNW-ESE oriented $\sigma 1$ principal axis to a $\sim$ NE-SW oriented compression. The system comprises NE-SW- to W-E-trending sinistral faults associated with NE-SW-striking quartz veins that occur partly in tension gashes (Fig. 11).

Steeply NE-dipping planes and a set of parallel narrow fracture zones truncate granodiorites that are exposed southeast of the Riukka prospect. The fracture zones represent fine-grained cataclasites leading to tectonic brecciation of the granodiorite. Based on their very brittle deformation style they might be attributed to $\mathrm{D}_{\mathrm{n}+4}$, though there is no direct field evidence for this assumption since they could have opened as extensional fractures during $\mathrm{D}_{\mathrm{n}+3}$ WSWENE compression as well.

Pre-existing faults and shear zones that have formed during earlier phases (e.g. $\mathrm{D}_{\mathrm{n}+3}$ ) have been reactivated, sometimes inversely, according to their orientation in the new stress field. SW-NE- to WSWENE-striking $\mathrm{D}_{\mathrm{n}+3}$ dextral or oblique contractional faults would have been reactivated inversely as extensional or sinistral faults. Overprinting of earlier fabrics probably also occurred along NW-SE oriented faults, which already formed during $\mathrm{D}_{\mathrm{n}+3}$ or even $\mathrm{D}_{\mathrm{n}+2}$ (e.g. as tear faults connecting variously displaced segments of a thrust).

The structural map (Fig. 2) shows open refolding of $\mathrm{F}_{\mathrm{n}+2}$ folds around NW-SE oriented axes. These fold axes would correspond well to $\mathrm{D}_{\mathrm{n}+4}$ NE-SW compression so that they are labelled $\mathrm{F}_{\mathrm{n}+4}$ in the map. However, this not unequivocal, and it is not clear whether the folds have formed during this stage, either contemporaneously or slightly prior to the faults, or if they represent a separate deformation phase.

\section{Mineralization}

The mineralized altered and veined zone in Riukka extends more than one $\mathrm{km}$ long and has a width of hundreds of metres; in the Satulinmäki prospect the mineralised zone is $>500 \mathrm{~m}$ long (Kärkkäinen \& Lehto, 2004).

The general alteration in the metavolcanic rocks 


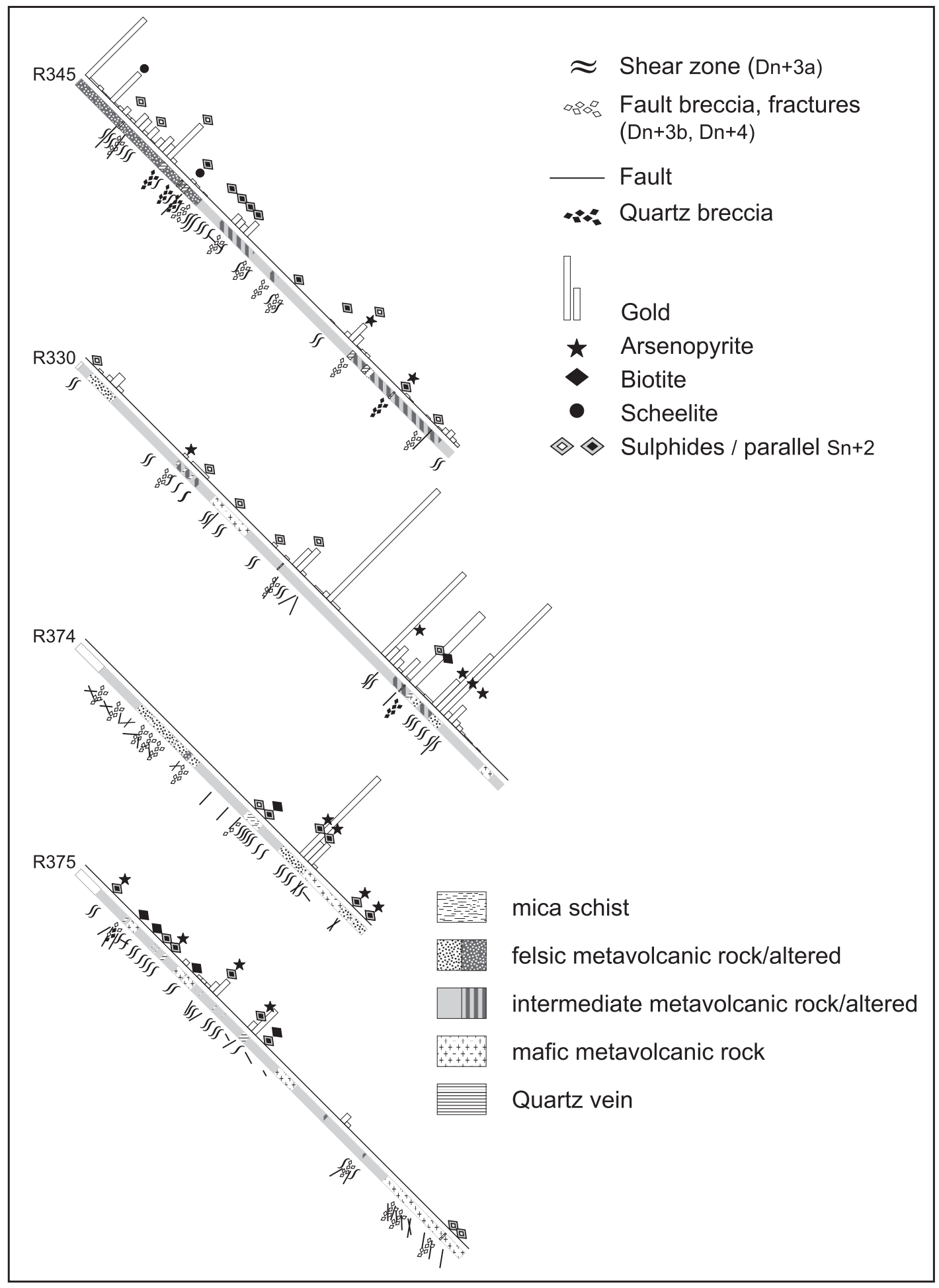

Fig. I2. Graphic logs of drill cores from Satulinmäki and Riukka illustrating the distribution of lithologic units, observed structures and mineralization including gold (columns show not measured gold grades but the length shows relative contents). Note the close relationship of mineralization to $D_{n+3}$ shear zones and to (semi-)brittle faulting and brecciation $\left(D_{n+3 b}\right)$. Further reactivation and brecciation could have occurred during $D_{n+4^{\circ}}(R 330+R 345$ : Satulinmäki, R374 + R375: Riukka) 
of the gold prospects comprises mainly silicification and formation of sulphides and tourmaline in Satulinmäki (Perälä, 2003; Kärkkäinen et al., 2003) and dominantly biotitisation in Riukka. The major sulphide minerals in both prospects are arsenopyrite and pyrrhotite (Perälä, 2003). Highest gold amounts range up to ca. 35 ppm in Riukka and 32 ppm in Satulinmäki in one $\mathrm{m}$ drill section.

Mineralisation is closely related to quartz veins (Fig. 10d), and likewise gold occurs in quartz-tourmaline veins; however, it is not restricted to them. In Riukka, however, higher gold contents are locally closely linked to a specific type of quartz vein, which contains $\mathrm{Zn}$, As, and some Cu. Gold is typically spatially associated with arsenopyrite (Fig. 12), but high arsenopyrite contents are not necessarily related to high gold concentrations and vice versa. Petrographic studies demonstrate that gold is situated as inclusions and at grain boundaries of arsenopyrite, and is typically associated with bismuth (Riukka) and antimone (Satulinmäki) minerals (Perälä, 2003).

Drill core data display a clear SW-NE trend of elevated gold contents. It is striking that higher gold concentrations, in addition to quartz veins, are in most cases spatially associated with $\mathrm{D}_{\mathrm{n}+3}$ shear zones and faults (typically in brittle reactivated $\mathrm{D}_{\mathrm{n}+3}$ shear zones) (Fig. 12). As described above, shear zones, several $\mathrm{dm}$ to $\mathrm{m}$ in size, in Satulinmäki are surrounded by altered wall rocks, and commonly these zones, which are truncated by numerous thin quartz veins, show the increased gold contents. $\mathrm{D}_{\mathrm{n}+3}$ shearing and faulting therefore played a key role in the deposition as is corroborated by the fact that many gold-bearing quartz veins occur preferentially close to major faults and either occur as bundles of thin veins within the shear zones or have sheared margins (thicker veins). The importance of tectonic structures on gold deposition can also be inferred from the 3D modelling of drill core data and faults. A projection of drill core data to the structural maps of the two prospects illustrates the spatial relationship of elevated gold contents in the vicinity to WSW-ENE to SW-NE striking and NW-SE trending faults and shears, and especially at intersection points of the two fault sets (Fig. 13, 14).
The lithology may also have had an influence on the precipitation sites, though to a much lesser extent than the structural control. Although lithological controls on gold cannot be observed - not considering auriferous quartz veins that contain especially high concentrations - high gold contents occur preferentially in felsic and intermediate metavolcanic rocks, which are the more competent rock types in this area with the felsic rocks being the most competent units. Mafic metavolcanic and granodioritic to tonalitic rocks as well as mica schists in contrast show only few sites of minor contents. The latter, however, constitute only minor portions of the rock column in this area.

In summary, gold precipitation is interpreted to be linked to $D_{n+3}$ starting either already during early stages $\left(\mathrm{D}_{\mathrm{n}+3 \mathrm{a}}\right)$ and/or occurring mainly during later, more brittle stages $\left(\mathrm{D}_{\mathrm{n}+3 \mathrm{~b}}\right)$ (Tab. 1). The latter would be supported by the observed low-temperature deformation of the quartz veins (see above). Enhanced fluid flow during $\mathrm{D}_{\mathrm{n}+3}$ is probably also the cause for locally intense retrograde sericitization of feldspar in many rocks.

\section{Discussion}

\section{I. Structural control on mineralization}

At least four deformation phases can be distinguished in the Forssa area comprising two phases of ductile folding and shearing $\left(\mathrm{D}_{\mathrm{n}+1}, \mathrm{D}_{\mathrm{n}+2}\right)$, possibly associated with (ductile) thrusting, followed by shearing and faulting during dextral transpression with - WNWESE shortening $\left(\mathrm{D}_{\mathrm{n}+3}\right)$, and finally faulting and fracturing of the rocks in a changed stress field $(\sigma 1=\mathrm{NE}$ $S W)$. Several generations of quartz veins can be identified ranging from strongly deformed, pre- to syn$\mathrm{D}_{\mathrm{n}+1}$ veins to late- to post tectonic veins associated with brittle fracturing of the host rock. The pattern of various veins and faults indicate a multiple-stage quartz vein formation associated with shearing and faulting in various stress regimes.

Many shear zones, faults and fractures show a multiple-stage overprinting history. Even during a single phase, e.g. $\mathrm{D}_{\mathrm{n}+3}$ and $\mathrm{D}_{\mathrm{n}+4}$, single reactivated faults 


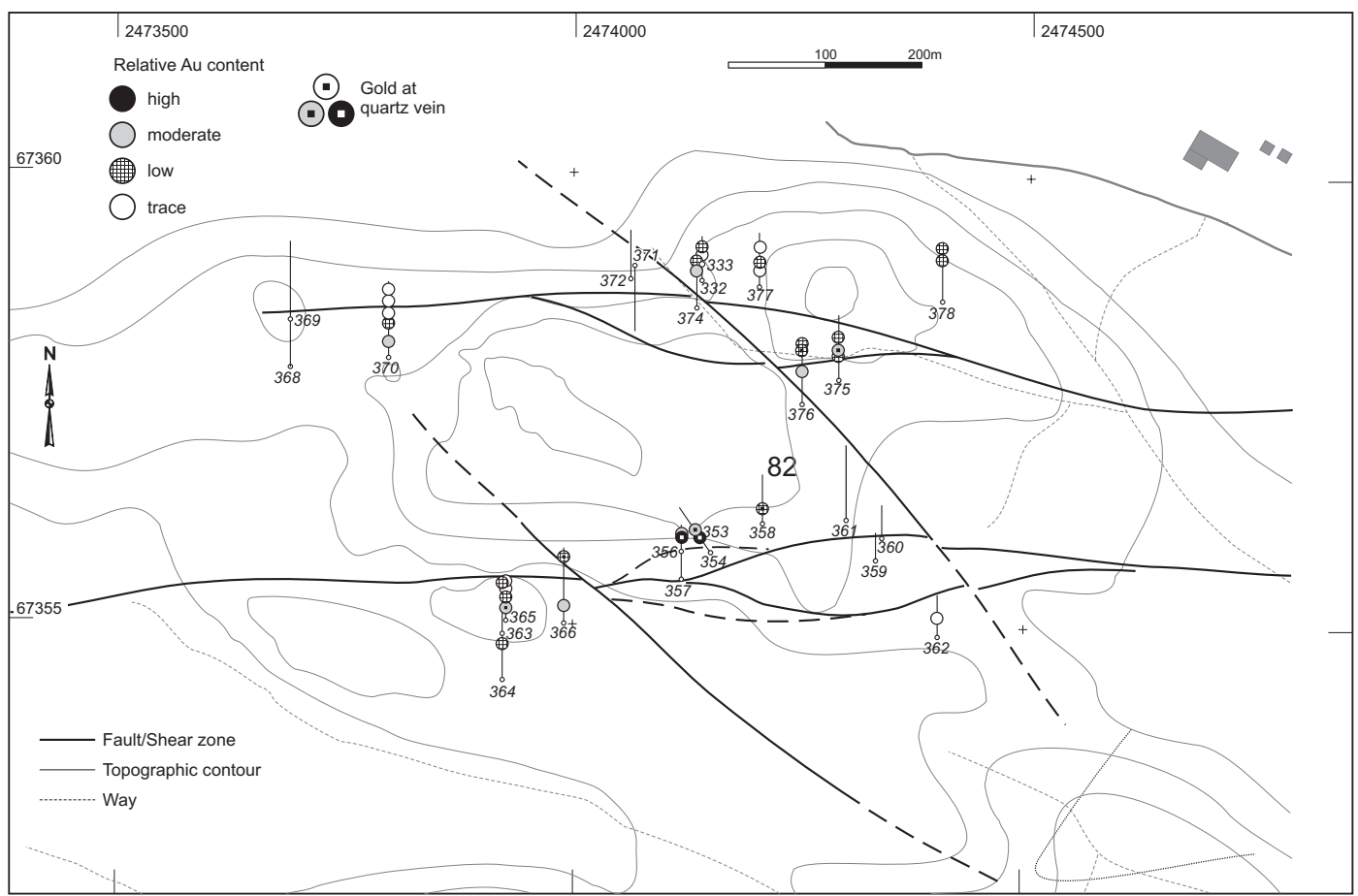

Fig. 13. Map of the Riukka prospect showing the main structures, drill hole locations and approximate gold concentrations projected to the surface. Elevated gold contents occur preferentially at quartz veins and close to major faults. The intersection points of WSW-ENE- and NW-SE-striking faults are favourable sites for gold as well.

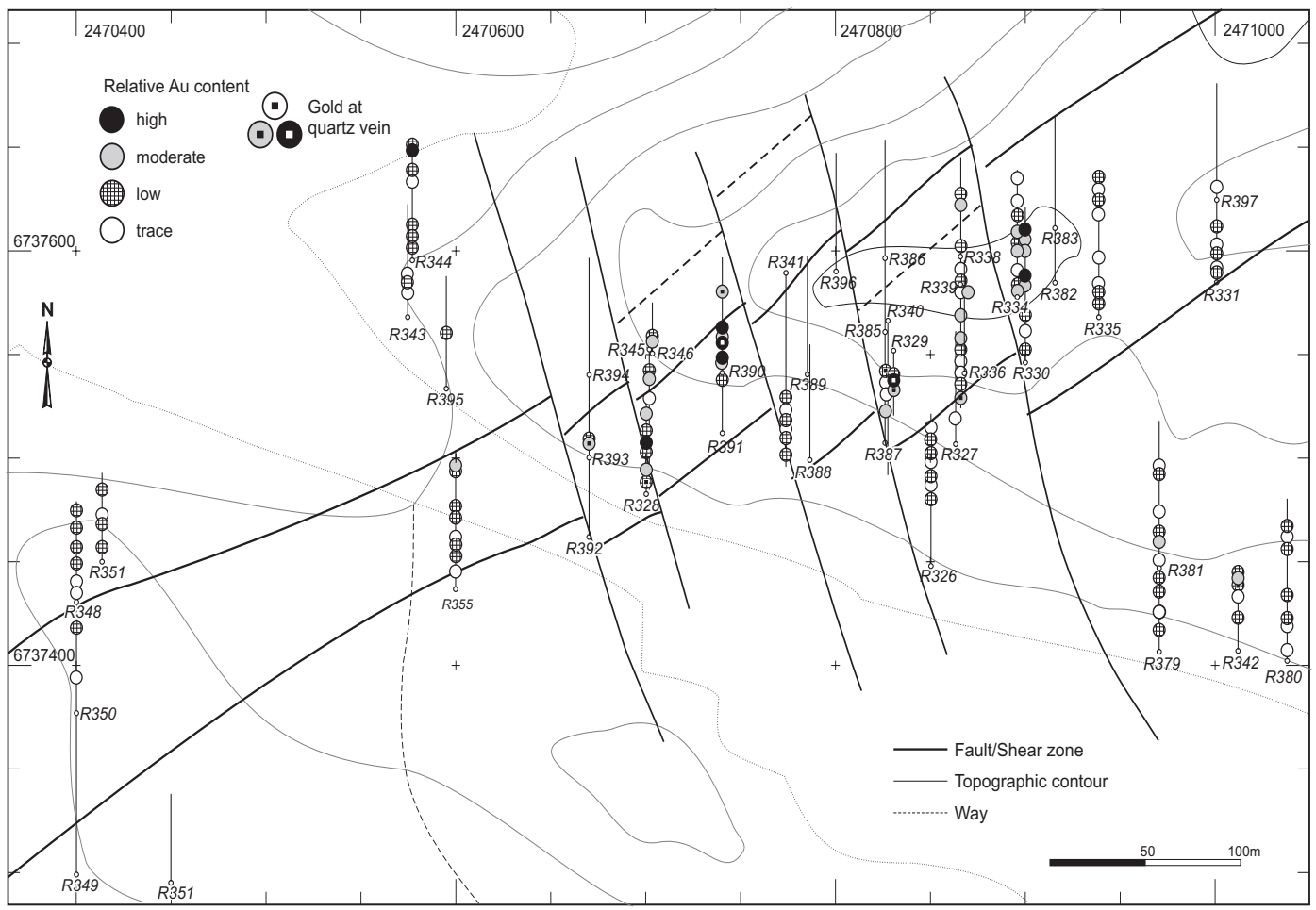

Fig. 14. Tectonic map of the Satulinmäki prospect with drill cores and approximate gold concentrations projected to the surface illustrating the strong structural control on gold deposition. Like in Riukka, intersection points of SWNE and NW-SE striking faults and shear zones play a major role in gold transport and precipitation. 

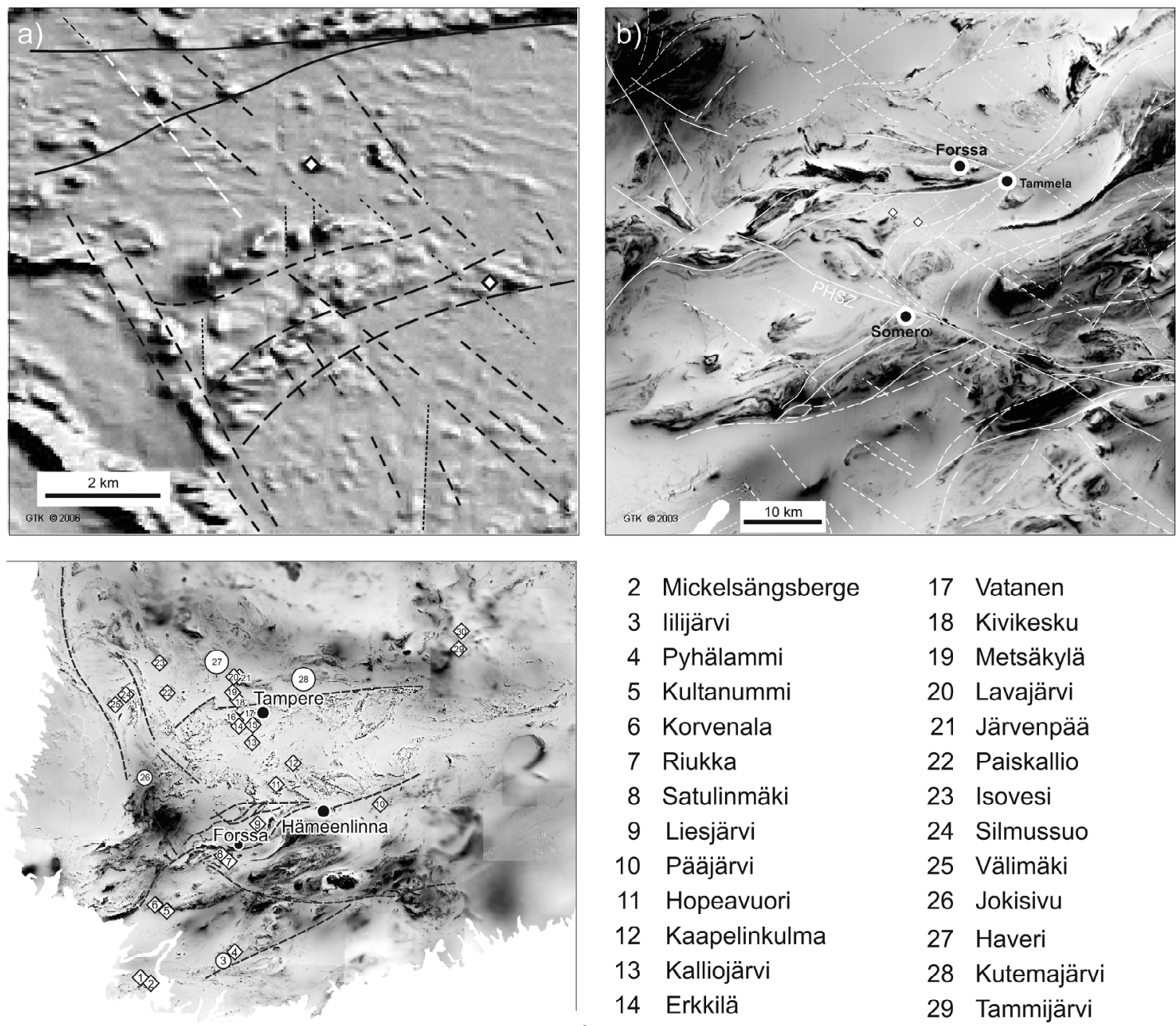

\begin{tabular}{|ll}
2 & Mickelsängsberge \\
3 & lilijärvi \\
4 & Pyhälammi \\
5 & Kultanummi \\
6 & Korvenala \\
7 & Riukka \\
8 & Satulinmäki \\
9 & Liesjärvi \\
10 & Pääjärvi \\
11 & Hopeavuori \\
12 & Kaapelinkulma \\
13 & Kalliojärvi \\
14 & Erkkilä \\
15 & Kaitajärvi
\end{tabular}

$\begin{array}{ll}17 & \text { Vatanen } \\ 18 & \text { Kivikesku } \\ 19 & \text { Metsäkylä } \\ 20 & \text { Lavajärvi } \\ 21 & \text { Järvenpää } \\ 22 & \text { Paiskallio } \\ 23 & \text { Isovesi } \\ 24 & \text { Silmussuo } \\ 25 & \text { Välimäki } \\ 26 & \text { Jokisivu } \\ 27 & \text { Haveri } \\ 28 & \text { Kutemajärvi } \\ 29 & \text { Tammijärvi } \\ 30 & \text { Vatsa }\end{array}$

GTK $\odot 2006$

Fig. 15. Processed aeromagnetic maps and main faults in the surroundings of the Satulinmäki and Riukka prospects a) and in the Forssa-Somero area b). The NW-SE alignment of the two gold prospects corresponds with the orientation of NW-SE faults indicating the importance of these structures on gold deposition. NW-SE faults are widespread in the whole area; they are parallel to the major Painio-Hirsjärvi shear zone (PHSZ). c) Aeromagnetic map containing locations of gold prospects and mines (circles) in southern Finland. Note the SW-NE alignment of prospects in the SW and S of Forssa and Hämeenlinna (and the NW-SE alignment on a smaller sale) and the NW-SE trend of gold deposits between Hämeenlinna and Tampere.

may display various slip directions since it is a common feature that single principal stress axes might temporally flip around the mean direction. Hence, the structural evolution, especially during $\mathrm{D}_{\mathrm{n}+3}$, but also during $\mathrm{D}_{\mathrm{n}+4}$, offered possibilities for a number of various fluid flow episodes. Formation of various quartz veins is likewise not restricted to $\mathrm{D}_{\mathrm{n}+3}$ but also occurred prior or during $\mathrm{D}_{\mathrm{n}+1}\left(\mathrm{~F}_{\mathrm{n}+1}\right.$ isoclinally folded quartz veins), probably from fluids that were released during prograde metamorphism, and $\mathrm{D}_{\mathrm{n}+4}$ (quartz in veins and tension gashes). Auriferous quartz veins, however, formed mainly during $\mathrm{D}_{\mathrm{n}+3}$ and, as demonstrated above, gold is clearly related to $\mathrm{D}_{\mathrm{n}+3}$ structures. Hence, gold mineralization post-dates the metamor- 


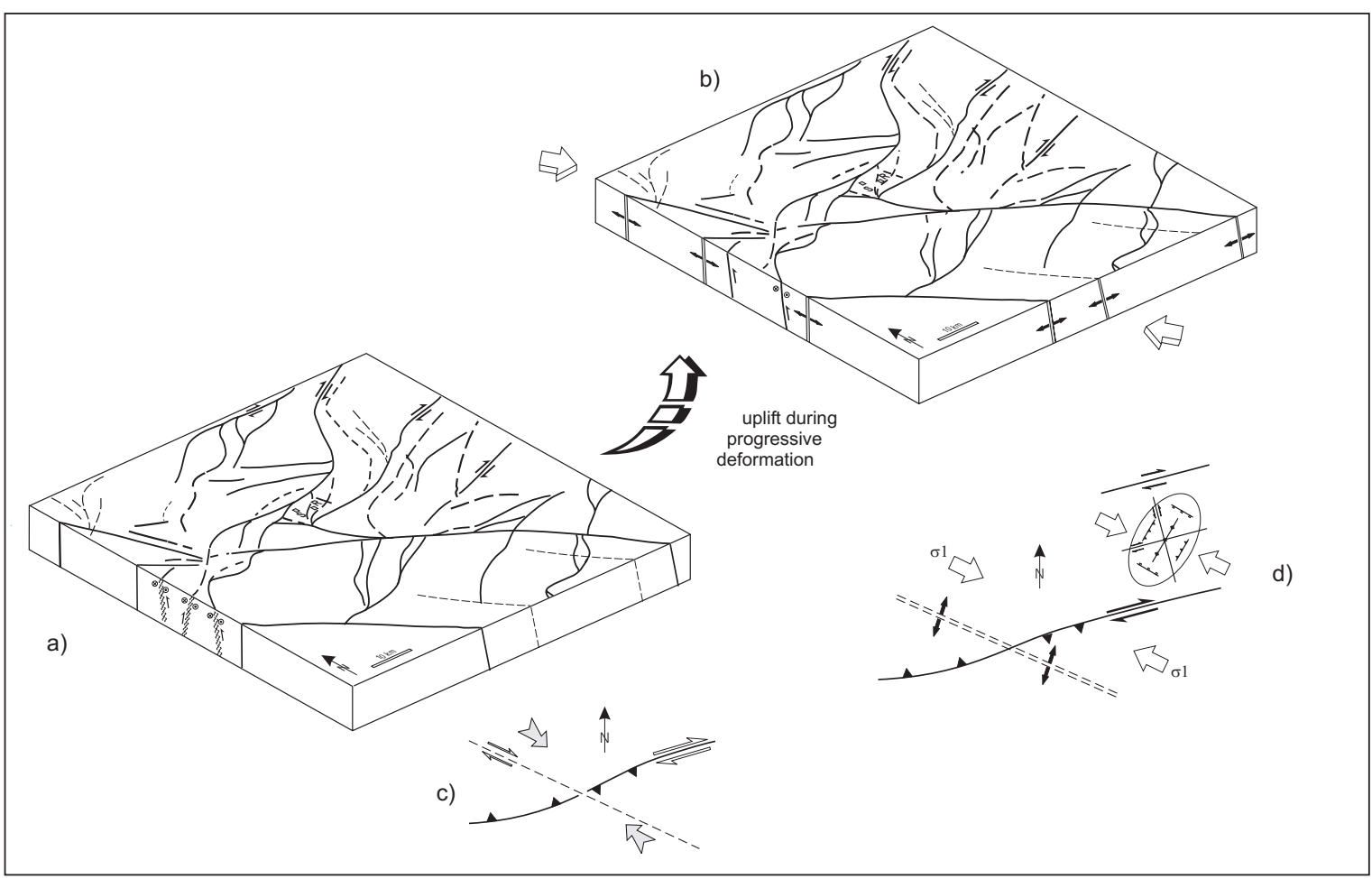

Fig. 16. Model for the progressive deformation during $D_{n+3}$ starting in ductile to semi-brittle conditions a) and crossing the ductile-brittle boundary leading to brittle faulting b) due to uplift. Especially in brittle conditions WNW-ESE compression leads to brittle extensional faulting along WNW-ESE to NW-SE oriented structures, which the could act as ore-fluid pathways. c) Early $D_{n+3}$ dextral transpression (thrusting and dextral shearing) due to WNW-ESE to NW-SE oriented maximum principal stress, possibly already starting in the late stages of $D_{n+2}$. (W)NW-(E)SE oriented faults could have formed as tear faults during thrusting and would have been reactivated during transpression. d) Stress ellipse for brittle $\mathrm{Dn}+3$ faulting.

phic peak. $\mathrm{D}_{\mathrm{n}+3}$ quartz vein formation took place during cooling of the rock through brittle-ductile transition and during dextral transpression. There is a strong structural control on mineralization. The controlling structures, (i) WSW-ENE to SW-NE shear zones and faults and (ii) NW-SE oriented faults, are apparent at a variety of scales. The Satulinmäki and Riukka prospects are typically sited at second and third order structures near major regional-scale NWSE and WSW-ENE to SW-NE shear zones and faults (Fig. 15), i.e. the NW-SE striking Painio-Hirsjärvi shear zone (PHSZ in Fig. 2) and the E-W oriented Hämeenlinna shear zone (north of the study area).

Fluid flow is strongly controlled, among other factors, by permeability, fluid pressure and a hydraulic gradient. The controlling shear zones/faults as well as the intersection points of the two sets impart a directional permeability so that the mineralising fluids were channelled in these structures. Multiple reactivations during progressive deformation and thus \pm continuous slip along the faults would have enhanced the channelling effect (Sibson \& Scott, 1998).

The NW-SE-trending faults, having formed either already during late stages of $D_{n+2}$ or during $D_{n+3}$, are optimally oriented for (re)activation as extensional faults or fractures during $\mathrm{D}_{\mathrm{n}+3}-$ WNW-ESE compression (Fig. 16), especially during the more brittle $D_{n+3 b}$ stage. The steep faults would act as conduits for fluids during upward flow from deeper crustal levels. The fluid flow along WSW-ENE to SW-NE-striking structures would occur along dilatant zones like dilatant jogs or fault oversteps. 
$\mathrm{D}_{\mathrm{n}+3}$ structures are in many places oriented subparallel or at an acute angle to the foliation. Fluid flow parallel to foliation planes would have enabled wider dissemination of the mineralising fluids and could explain that the gold mineralization, despite the clear spatial association of high contents to shear zones and quartz veins, is not totally restricted to narrow zones but anomalous gold contents might occur along the whole drill core.

The above described features of both prospects like occurrence in metamorphic terrains, association with compressional/transpressional deformation, strong structural control of mineralization, coexistence of ductile and brittle structures, mineralization occurring during the later, retrograde stages of orogenic evolution as well as the importance of auriferous quartz veins are typical of orogenic gold deposits (e.g. Groves et al., 1998), and the two prospects would correspond well to mesothermal orogenic gold sensu Groves et al. (1998). The tectonic setting of an accretionary orogen resulting from subduction of oceanic crust also fits well (Kerrich \& Wyman, 1990; Groves et al., 1998).

\subsection{Regional implications}

A number of gold prospects have been investigated in southern Finland, which represent various genetic types like metamorphosed epithermal, orogenic mesothermal, massive sulphide, and submarine hydrothermal, whereas for some prospects, the origin is not resolved (FINGOLD public database). At regional scale, many prospects in southern Finland seem to be controlled by shear zones or faults, mostly striking SW-NE to W-E. This is also reflected in the SW-NE alignment of gold prospects in the southern regions (Häme and Uusimaa belts) (Fig. 15c). Within single prospect areas, a NW-SE alignment of neighbouring prospects is recognizable, like for example of Kultanummi and Korvenala and Riukka and Satulinmäki. Further north the gold occurrences define a NW-SE trend. However, it is not yet studied if individual gold deposits, which have different origins and structural settings in the Häme belt and possibly also in other areas in southern Finland, are temporarily linked or whether they belong even to the same tectonic regime and event. To understand the origin, timing, and possible genetic connections detailed studies are necessary concerning (i) the structural control on gold deposition, (ii) the timing of mineralization, relative in the structural history as well as by dating of mineralization, and (iii) a comparison of deformation episodes and mineralization styles of different deposits.

Gold mineralization occurred late orogenic in most cases implying that different tectonic blocks and even terranes have already been juxtaposed. A dominance of (W)SW-(E)NE and NW-SE oriented structures also in regions north of the Häme belt is obvious, but the NW-SE alignment of a number of gold occurrences further north between Tampere and Hämeenlinna (Fig. 15) is striking as well. This alignment might be due to NW-SE oriented semi-brittle to brittle faults acting as fluid pathways, which could suggest a possible temporal and spatial relationship to the orogenic gold mineralization in the Häme belt and thus genetic links between distant deposits of previously attached but originally different tectono-stratigraphic blocks. On the other hand, however, many gold prospects cannot be correlated. The Jokisivu gold deposit, for example, located in the Vammela migmatite zone (Pirkanmaa belt), did not form in a late tectonic stage at brittle conditions although it is associated with a NW-SE striking shear zone. This zone, however, formed during an early stage close to peak metamorphic conditions and thus, cannot be linked with the brittle NW-SE-striking faults elsewhere. Hence, it is unlikely that gold mineralization in southern Finland was connected to a single event. It is suggested that some gold mineralisation occurred prior to the main deformation (e.g. submarine hydrothermal deposits) while others formed during several episodes either pre-, syn- or post-peak metamorphic leading to temporally and spatially varying mineralization. Despite these differences prospects of orogenic gold linked to late-orogenic mineralization might show similarities in style, timing and structural control.

About $90 \%$ of all Finnish gold prospects can be classified as orogenic (Eilu et al., 2003) implying a 
strong structural control on mineralization and thus a link to regional-scale and local-scale structures like shear zones and faults. Future prospecting should focus on second- and third-order structures branching from major shear and fault zones. Applying this to the Häme schist belt, prospecting should consider intersection points of (W)SW-(E)NE- and NWSE-striking faults and look for second and third order structures at these sites. Aerogeophysical data and maps turned out to be especially useful for identification and evaluation of major folds and faults in the Häme schist belt. In addition, other important controls like lithology (competent rock units like felsic metavolcanic rocks), competency contrasts between different rock types and existence of older structures capable for reactivation, both giving rise to heterogeneous stress distribution, and other structures like fold hinges should be taken into account. If this approach could be transferred also to regions further north, i.e. prospects in the Tampere and Pirkanmaa belts, remains open though and has to be tested.

\section{Conclusions}

The Satulinmäki and Riukka gold occurrences are located in a 1890 - 1880 Ma metavolcano-sedimentary succession deposited in a continental arc setting during the Svecofennian orogeny. The structural succession comprises at least 3 ductile to semi-brittle deformation phases followed by brittle fault tectonics.

The dominant penetrative foliation is represented by $S_{n+1}$, which is axial planar to $\mathrm{cm}$ - to $\mathrm{dm}$-scale iscolinal $\mathrm{F}_{\mathrm{n}+1}$ folds. $\mathrm{D}_{\mathrm{n}+1}$ was accompanied by ductile shearing (thrusting) and marks the metamorphic peak. During $\mathrm{D}_{\mathrm{n}+2}$ earlier structures have been folded around ca. SW-NE-trending fold axes. $\mathrm{F}_{\mathrm{n}+2}$ folds range from $\mathrm{cm}$ - to regional-scale. Progressive deformation led to development of SW-NE- to WSWENE- and NW-SE-striking shear zones and faults formed due to dextral transpression. This $\mathrm{D}_{\mathrm{n}+3}$ phase took place at retrograde conditions crossing the brittle-ductile transition. Many mineralized quartz veins have formed during this event. Rotation of the stress field to $\sim$ NE-SW oriented compression marks a sub- sequent fault event, $\mathrm{D}_{\mathrm{n}+4}$, leading to formation of faults and quartz veins.

The SW-NE trend of sulphide mineralization and elevated gold contents and the spatial association to $\mathrm{D}_{\mathrm{n}+3}$ quartz veins, shear zones and faults suggest a strong structural control on mineralization that took place during $\mathrm{D}_{\mathrm{n}+3}(\mathrm{~W}) \mathrm{NW}$-(E)SE oriented dextral transpression. The gold occurrences show typical features of orogenic gold. The controlling structures are $\mathrm{D}_{\mathrm{n}+3}$ WSW-ENE to SW-NE shear zones and faults as well as NW-SE oriented faults, both are second and third order structures to major regional-scale shear zones. Extensional fractures and dilatant jogs or fault oversteps along the steep faults represented good pathways for fluid flow, in particular during the more brittle $\mathrm{D}_{\mathrm{n}+3 \mathrm{~b}}$ stage.

Future studies in the Häme belt are necessary to test whether other prospects show similar timing and structural control. Future exploration for finding new targets should consider sites of (W)SW-(E)NE and NW-SE-striking second and third-order structures branching from major shear and fault zones, and should focus in particular on intersection points of the fault sets.

\section{Acknowledgements}

The presented studies are part of the "Geological and metallogenic modeling"-project. The author would like to thank N. Kärkkäinen and M. Tiainen for fruitful discussions in the field and on the manuscript. M. Paananen's help and instruction how to use specific SURPAC features are gratefully acknowledged as is the constructive review of J. Ojala.

\section{References}

Eilu, P., Sorjonen-Ward, P., Nurmi, P. \& Niiranen, T., 2003. A review of gold mineralization styles in Finland. Economic Geology 98, 1329-1353.

FINGOLD public database, Geological Survey of Finland, editor: P. Eilu. http://en.gtk.fi/ExplorationFinland/ Commodities/Gold/gtk_gold_map.html

Groves, D.I., Goldfarb, R.J., Gebre-Mariam, M., Hagemann, S.G. \& Robert, F., 1998. Orogenic gold deposits: A proposed classification in the context of their crustal 
distribution and relationship to other gold deposit types. Ore Geology Reviews 13, 7-27.

Hakkarainen, G., 1994. Geology and geochemistry of the Hämeenlinna-Somero volcanic belt, southwestern Finland: a Paleoproterozoic island arc. In: Nironen, M. \& Kähkönen, Y. (eds.) Geochemistry of Proterozoic supracrustal rocks in Finland. Geological Survey Special publication 19, 85-100.

Huhma, H., Claesson, S., Kinney, P.I. \& Williams, I.S., 1991. The growth of Early Proterozoic crust: new evodence from Svecofennian detrital zircons. Terra Nova 3, 175-179.

Kerrich, R. \& Wyman, D., 1990. Geodynamic setting of mesothermal gold deposits: An association with accretionary tectonic regimes. Geology 18, 882-885.

Kähkönen, Y., 2005. Svecofennian supracrustal rocks. In: Lehtinen, M., Nurmi, P.A. \& Rämö, O.T. (eds.) Precambrian Geology of Finland - Key to the Evolution of the Fennoscandian Shield. Elsevier B.V, Amsterdam, pp. 343-406.

Kärkkäinen, N. \& Lehto, T., 2004. GTK:n kultatutkimukset Etelä- ja Länsi-Suomessa. Vuorimiesyhdistyksen ekskursio 28.9.2004-29.9.2004. Geological Survey of Finland, Report M 19/2024/2004/2/10, 11 p.

Kärkkäinen, N., Lehto, T., Tiainen, M., Jokinen, T., Nironen, M., Peltonen, P. \& Valli, T. 2003. Etelä- ja LänsiSuomen kaarikompleksi, kullan ja nikkelin etsintä vuosina 1998-2002. Geological Survey of Finland, Report M19/21,12/2003/1/10, 118 p.

Lahtinen, R. 1996. Geochemistry of Paleoproterozoic supracrustal and plutonic rocks in the Tampere-Hämeenlinna area, southern Finland. Geological Survey of Finland, Bulletin 389, 113 p.

Lahtinen, R. \& Huhma, H., 1997. Isotopic and geochemical constraints on the evolution of the 1.93-1.79 Ga Svecofennian crust and mantle. Precambrian Research 82, 13-34.

Lahtinen, R. , Korja, A. \& Nironen, M., 2005. Paleoproterozoic tectonic evolution. In: Lehtinen, M., Nurmi, P.A. \& Rämö, O.T. (eds.) Precambrian Geology of Finland - Key to the Evolution of the Fennoscandian Shield. Elsevier B.V., Amsterdam, pp. 481-532.

Niironen, M., 1999. Structural and magmatic evolution in the Loimaa area, southwestern Finland. In: Kähkönen, Y. \& Lindquist, K. (eds.) Studies related to the Global Geoscience Transect/SVEKA Project in Finland. Bulletin of the Geological Society of Finland 71, 57-71.

Perälä, A. 2003. Someron Satulinmäen Au-esiintymän geologia, geokemia ja mineralogia. M.Sc. Thesis., University of Oulu, Finland, 57 p.

Rämö, O.T., Vaajoki, M., Mänttäri, I., Elliott, B.A. \& Nironen, M., 2001. Petrogenesis of the post-kinematic magmatism of the Central Finland Granitoid Complex I: radiogenic isotope constraints and implications for crustal evolution. Journal of Petrology 42, 1971-1993.

Sibson, R.H. \& Scott, J., 1998. Stress / fault controls on the containment and release of overpressured fluids: Examples from gold-quartz vein systems in Juneau, Alaska; Victoria, Australia and Otago, New Zealand. Ore Geology Reviews 13, 293-306.

Stipp, M., Stu“nitz, H., Heilbronner, R., Schmid, S.M., 2002. The eastern Tonale Fault fault zone: A'natural laboratory' for crystal plastic deformation of quartz over a temperature range from 250 to $700^{\circ} \mathrm{C}$. Journal of Structural Geology 24, 1861-1884.

Suominen, V., 1988. Isotopic ages on zircons from a cogenetic gabbro and plagioclase porphyrite suite in $\mathrm{Hy}-$ vinkää, southern Finland. Bulletin of the Geological Society of Finland 60, 135-140.

Vaasjoki, M., 1994. Valijärven hapan vulkaniitti: minimi Hämeen linskejakson iäksi. Summary: Radiometric age of a meta-andesite at Valijärvi, Häme Schist zone, southern Finland. Geologi 46, 91-92.

Vaasjoki, M., Korsmann, K. \& Koistinen, T., 2005. Overview. In: Lehtinen, M., Nurmi, P.A. \& Rämö, O.T. (eds.) Precambrian Geology of Finland - Key to the Evolution of the Fennoscandian Shield. Elsevier B.V., Amsterdam, pp. 1-18.

Väisänen, M., Mänttäri, I. \& Hölttä, P., 2002. Svecofennian magmatic and metamorphic evolution in southwestern Finland as revealed by U-Pb zircon SIMS geochronology. Precambrian Research 116, 111-127. 